\title{
Strategi Dakwah Kultural Muhammadiyah pada Ritual Adat Mappogau Hanua Masyarakat Karampuang Sinjai
}

DOI 10.18196/AIIJIS.2017.0073.204-239

\section{UMAR}

Institut Agama Islam Muhammadiyah Sinjai

oemar.beksam@yahoo.com

\section{ABSTRACT}

This article examines dakwah movement and Islamic reform mission in the Karampuang, an area whose society preserve cultural heritage of Mappogau Hanua. Cultural dakwah is used by Muhammadiyah as a strategy to cope with the local culture and costumary tradition of Mappogau Hanua. This article finds that a series of customary practice of rituals of Mappogau Hanua in Karampuang society have been modified by the Muhammadiyah's cultural dakwah movement. The Muhammadiyah dakwah strategies can be seen in three asepcts. First, participative strategy and family engagement have been used to understand costumary practice of the local tradition and the way to modify it. Second, to change people's way of thinking (mindset) in understanding Mappogau Hanua ritual, especially in conceiving the ritual practice of Mabbahang, Mappaota, Mabbaja-baja (membersihkan), Menre Ri Bulu, Mabbali Sumange' dan Malliing. Third, educative strategy I sued by assisiting and empowering adat policy, education, religious activities, health care, and the authority of adat sustainably. Based on these three strategies of cultural dakwah, Muhammadiyah remains exist and accepted in Karampuan society.

Keyword: cultural Dakwah, Muhammadiyah, Adat, Karampuang Community

\section{ABSTRAK}

Kajian artikel ini membahas gerakan dakwah dan misi pembaharuan islam dalam Masyarakat Karampuang, sebuah daerah yang secara kultural masih mempertahankan tradisi kepercayaan leluhur adat Mappogau Hanua. Dakwah kultural digunakan sebagai strategi adat istiadat Mappogau Hanua. Artikel ini melihat bahwa berbagai kegiatan ritual dan adat istiadat Mappogau Hanua dari masyarakat Karampuan telah mendapatkan medifikasi dari gerakan 
Muhammadiyah. Strategi gerakan dakwah kultural Muhammadiyah dapat dilihat dari tiga aspek. Pertama, strategi partisipatif dan kekeluargaan relah digunakan untuk memahami masyarakat adat tradisi local dan bagaimana cara memodifikasinya. Kedua, strategi perubahan pola pikirdalam memahami rangkaian ritual Mappogau Hanua khususnya dalam rangkaian Mabbahang, Mappaota, Mabbaja-baja, Menre Ri Bulu, Mabbali Sumange' dan Malliing. Ketiga, strategi pembinaan (yakni pendampingan dan penguatan pondasi kebijakan pemerintahan adat, pendidikan, keagamaan dan kesehatan dalam otoritas pilar adat secara berkelanjutan). Dengan berangkat pada tiga strategi dakwah kultural tersebut nampaknya Muhammadiyah masih bisa eksis dan dapat diterima oleh masyarakat Karampuan.

Kata Kunci: Dakwah Kultural, Muhammadiyah, Adat, Masyarakat Karampuang

\section{PENDAHULUAN}

Muhammadiyah lahir sebagai gerakan dakwah amar ma'ruf nahi mungkar dan strategi dakwahnya terpusat pada gerakan tajdid dan purifikasi yakni gerakan yang menjaga kesucian dan kemurnian ajaran agama Islam sebagaimana ajaran Nabi Muhammad SAW. Muhammadiyah dengan gerakan pemberantasan bentuk-bentuk takhyul, bid'ah, dan churafat (TBC) yang pada prakteknya saat ini masih banyak berkembang di tengah masyarakat Islam. Sairin mengemukakan bahwa "bentuk-bentuk kegiatan yang masuk pada wilayah TBC, antara lain; selamatan pada waktu orang meninggal (termasuk selamatan pada wanita mengandung dan wanita melahirkan), pengkeramatan kuburan suci (termasuk pengkeramatan pada wali atau kyai), upacara tahlil dan talqin, kepercayaan atas jimat, dan upacara menanam kepala kerbau (termasuk sedekah bumi, sedekah laut, dII). Untuk itu, dakwah Muhammadiyah banyak diarahkan untuk memberantas segala hal yang berbau TBC. ${ }^{1}$

Dakwah Muhammadiyah menurut Majelis Tabligh dan Dakwah Khusus PP Muhammadiyah, sebagai upaya menjadikan Islam agama rahmatanlit'alamin idealnya menyentuh segala lapisan dan kelompok masyarakat. Dakwah merupakan aktivitas menyeru manusia ke jalan Allah SWT (ajaran agama Islam) secara murni, sehingga dakwah dianggap sebagai perkara yang dharuri (sangat penting) bagi masyarakat di zaman modern dan globalisasi. Hal ini dipusatkan pada kondisi ummat Islam yang dalam praktek keberagamaanya telah melenceng dari syari'at Islam, disamping dakwah sebagai aktivitas mulia dan wajib bagi segenap muslim sebagaimana diisyaratkan dalam al-Qur'an surat Al-Imran:104,"Dan hendaklah ada di antara kamu segolongan umat yang menyeru kepada 
kebajikan, menyuruh kepada yang ma'ruf dan mencegah dari yang mungkar; mereka adalah orang-orang yang beruntung', (Q.S:3:104)"

Masyarakat"Islam sebagai pusat dakwah amat variatif dalam praktek keberagamaan baik pada masyarakat perkotaan maupun masyarakat lokal pedesaan. Secara kultural masyarakat lokal cenderung mempertahankan tradisi dan kepercayaan dengan hal-hal tertentu yang dinilai menyimpang dari kemurnian ajaran Islam. Kepercayaan masyarakat dengan sistem adatistiadat menjadi bagian dan terpatri dalam budaya keseharian. Varian kepercayaan di tengah dakwah Islam ini masih tumbuh subur khususnya di wilayah masyarakat dengan nuansa adat yang kental dengan budaya tradisional sehingga masyarakat di samping menjalankan syariat Islam juga menjalankan ritual kepercayaan yang dianggap bertentangan dengan ajaran Islam seperti upacara adat, ritual dan sebagainya yang bermotif aqidah, sehingga di sinilah peran pentingnya dakwah Islam untuk terus mengambil bagian sebagai gerakan pemurnian.

Eksistensi kepercayaan pada pelaksanaan upacara adat ditegaskan oleh Koenjtaraningrat bahwa kepercayaan yang mendorong manusia untuk melakukan berbagai perbuatan yang bertujuan mencari hubungan dengan dunia gaib penguasa alam melalui ritual-ritual, baik ritual keagamaan maupun ritual adat lainnya, adalah ketika masyarakat merasakan saatsaat genting yang dapat membawa bahaya, kesengsaraan, dan penyakit kepada manusia maupun tanaman. ${ }^{2}$ Ritual menurut Suprayogo adalah 'rangkaian kata, tindakan pemeluk agama dengan menggunakan bendabenda, peralatan dan perlengkapan tertentu, ditempat tertentu dan memakai pakaian tertentu pula. ${ }^{3}$ Pelaksanaan ritual adat tersebut menunjukkan urgensitas dan merupakan eksistensi kepercayaan dan suatu pengakuan pada hal gaib serta suatu simbol eksistensi suatu masyarakat adat.

Suatu praktek ritual yang secara intens pada akhirnya menjadi kebudayaan khas dan unik yang mungkin dapat berbeda dengan ritual masyarakat lainnya, sehingga perspektif yang dapat berkembang adalah ajaran Islam akan makin dijauhi. Dalam perspektif normatif dan antropologis praktek ritual dan kepercayaan dapat direspon melalui dakwah. Hafidudin berpendapat bahwa dalam al-Quran dan Sunnah dikemukakan dakwah menduduki tempat dan posisi sentral dan menentukan. Metode dakwah yang tidak tepat, sering memberikan gambaran dan pendapat yang keliru tentang Islam, sehingga 
kesalahlangkaan dalam operasional dakwah. ${ }^{4}$

Buku "Dakwah Kultural Muhammadiyah" terbitan Pimpinan Pusat Muhammadiyah" ${ }^{5}$ menekankan kegiatan dakwah sebagai kegiatan profetik menuju kemurnian ajaran Islam maka seiring perkembangan zaman, tantangan kehidupan sosial budaya maupun adat-istiadat budaya lokal kehidupan masyarakat Islam, kegiatan dakwah penting mengalami pengembangan format seperti dakwah jamaah dan dakwah kulural yang lebih aplikatif. Pelaksanaan dakwah kultural yang baik dan efektif dilaksanakan berdasarkan langkah-langkah dan ketentuan yang tepat sesuai kondisi dan objek masyarakat. Sehingga pembaruan strategi dakwah kultural dimaksudkan sebagai upaya mempercepat pemahaman dan pelaksanaan syariat Islam secara tepat dalam kehidupan sehari-hari pada masyarakat adat.

Sehubungan dengan dakwah klutural di masyarakat lokal, kampung adat Karampuang masih setia mempertahankan tradisi nenek moyang mereka, salah satunya adalah upacara adat Mappogau Hanua yang dilaksanakan rutin sekali dalam setahun. Menurut Muhannis bahwa upacara Mappogau Hanua ${ }^{6}$ menjadi semacam alat kontrol sosial yang mengatur ketertiban pola tingkah laku dan interaksi sosial serta prilaku keagamaan dalam masyarakat dan memiliki rasa emosi yang kuat. Motif keyakinan yang menjadi dasar dalam pelaksanaan upacara adat ini adalah subjektifitas keyakinanan masyarakat Karampuang, apabila warga tidak menjalankan ritual sesuai pesan leluhur, maka ancaman kehidupan berupa bencana akan terjadi, seperti; kemarau panjang, kebutuhan sandang pangan yang sulit, munculnya penyakit yang tidak ada obatnya.

Upacara adat Mappogau Hanua merupakan warisan leluhur masa lampau yang dijadikan sebagai pegangan kuat dalam eksistensi dan tradisi masyarakat Karampuang. Jika merujuk pada eksistensinya ini sampai sekarang, dapat memunculkan pertanyaan bahwa mungkinkah ajaran Islam jauh lebih berkembang secara rasional ditengah kepercayaan dan budaya adat Mappogau Hanua yang bermotif aqidah?, Menyikapi pertanyaan dan pandangan tersebut pembahasan berikut ini mencoba menguraikan tentang ritual Mappogua Hanua tersebut serta menegaskan operasional dan rambu-rambu dakwah kultural Muhammadiyah yang terintegral dalam praktek upacara adat Mappogau Hanuadi masyarakat Karampuang. 


\section{METODE PENELITIAN}

Penelitian ini dilakukan di masyarakat adat Karampuang desa Tompo Bulu kecamatan Bulupoddo Kabupaten Sinjai dengan memfokuskan pada upacara adat khususnya Mappogau Hanua dengan metode penelitian kualitatif deskriptif-eksploratif yakni dengan menelaah aspek sosiologi masyarakat adat, praktek upacara adat Mappogau Hanua maupun strategi dakwah kultural Muhammadiyah yang relevan dan dikembangkan melalui faktor persamaan dan perbedaan ajaran Islam (aqidah dan ibadah) dengan sistem kepercayaan, sosial dan budaya adat Karampuang. Mendesain praktek dakwah dengan nilai-nilai dalam upacara adat Mappogau Hanua. Metode pengumpulan data bersumber secara primer dengan observasi partisipan, wawancara mendalam (indept interview) melalui pemilihan informan secara snow ball sampling dan dokumentasi. Data-data sekunder yang relevan dengan menggunakan pendekatan dakwah sosiologis, teologi normatif, komunikasi, maupun pendekatan sejarah. Teknik analisis data dalam penelitian ini adalah model interaktif Miles dan Huberman yakni analisis data dilakukan saat pengumpulan data berlangsung, dan setelah pengumpulan data dalam periode tertentu dengan langkah reduksi, display dan verifikasi data ${ }^{7}$ sehingga dapat terungkap strategi dakwah kultural Muhammadiyah.

\section{MASYARAKAT ADAT DAN SISTEM KEPERCAYAAN}

Masyarakat adalah gabungan dari individu. Gabungan individu ini bervariasi dari yang terkecil (seperti rumah tangga), yang menengah (seperti desa), sampai ke yang besar (seperti etnik, suku bangsa dan bangsa); bervariasi dari yang tradisional, seperti suku, agama, dan etnis tertentu, sampai yang modern, seperti lembaga legislatif, partai politik dan lainnya. Kelompok-kelompok individu yang merupakan masyarakat atau unit-unit masyarakat yang bersifat komprehensif diikat oleh nilai dan code of conduct tertentu atau oleh philosofhy and way of life, ${ }^{8}$.Istilah "masyarakat adat" indigenous peoples pertama kali didefinisikan pada tahun 1993 di Toraja yang diartikan "sebagai kelompok masyarakat yang memiliki asal usul leluhur (secara turun temurun) diwilayah geografis tertentu, serta memiliki sistem nilai, ideologi, ekonomi, politik, budaya, sosial, dan wilayah sendiri."

Definisi "Masyarakat Adat" sebagaimana dirumuskan Aliansi Masyarakat Adat Nusantara (AMAN) dalam tuntutan Judicial Review (JR) terhadap 
UU No.41 tahun 1999 tentang Kehutanan, dengan definisi "sekelompok penduduk yang hidup berdasarkan asal-usul leluhur dalam suatu wilayah geografis tertentu, memiliki sistem nilai dan sosial budaya yang khas, berdaulat atas tanah dan kekayaan alamnya serta mengatur dan mengurus keberlanjutan kehidupannya dengan hukum dan kelembagaan adat. Sedangkan Keraf menyebutkan "ciri yang berkaitan dan membedakan masyarakat adat dari kelompok masyarakat lain yaitu; (1) mereka mendiami tanah-tanah milik nenek moyangnya baik seluruhnya maupun sebagian, (2) mereka mempunyai garis keturunan yang sama yang berasal dari penduduk asli daerah tersebut, (3). mempunyai budaya khas yang menyangkut agama, sistem suku dll, (4). Mempunyai bahasa sendiri" Pengertian tersebut menegaskan masyarakat adat merupakan suatu kelompok masyarakat yang hidup diatas suatu wilayah adat dengan mempertahankan keberlansungan hidup dan kehidupannya ditandai adanya ikatan kesejarahan, sistem dan tradisi kehidupan tradisional, budaya sosial secara mandiri dan bertahan.

Sistem kepercayaan yang dilakukan suatu masyarakat sangat erat kaitanya dengan istilah "aqidah" dan "ibadah". Menurut Al-Atsari kata"'Aqidah" diambil dari kata dasar "al-'aqdu" yaitu ar-rabth (ikatan), al-Ibraamal-ihkam (pengesahan), (penguatan), at-tawatstsuq (menjadi kokoh, kuat), asy-syaddu biquwwah (pengikatan dengan kuat), attamaasuk(pengokohan) dan al-itsbaatu (penetapan). Di antaranya juga mempunyai arti al-yaqiin (keyakinan) dan al-jazmu (penetapan). Secara terminologi, yaitu perkara yang wajib dibenarkan oleh hati dan jiwa menjadi tenteram karenanya, sehingga menjadi suatu kenyataan yang teguh dan kokoh, yang tidak tercampuri oleh keraguan dan kebimbangan. Jadi kesimpulannya, apa yang telah menjadi ketetapan hati seorang secara pasti adalah aqidah; baik itu benar ataupun salah. ${ }^{10}$

Dalam terminologi bahasa Indonesia khususnya dalam Kamus Besar Bahasa Indonesia (KBBI) kata "ibadah" memiliki arti: (1). Perbuatan atau penyataan bakti terhadap Allah atau Tuhan yang didasari oleh peraturan agama. (2). segala usaha lahir dan batin yang sesuai perintah agama yang harus dituruti pemeluknya. (3). upacara yang berhubungan dengan agama. ${ }^{11}$ Pengertian ini menjelaskan bahwa ibadah merupakan pembuktian manusia akan hal pengakuan kepada Tuhannya (Allah SWT) baik melalui pernyataan dan perbuatan yang dilakukan oleh suatu pemeluk agama atau kepercayaan. 


\section{KONSEP STRATEGI DAKWAH KULTURAL}

Strategi secara etimologis berasal dari kata majemuk bahasa Yunani stratos, yang berarti pasukan dan agein yang berarti memimpin. Pada perkembangan selanjutnya, strategi juga dipergunakan di lingkungan lain seperti strategi politik, strategi ekonomi, strategi sosial, strategi budaya dan juga strategi dakwah. Secara istilah "strategi" merupakan aktivitas menentukan cara bertindak atau rencana kegiatan jangka panjang atau pemilihan bidang kegiatan yang akan dilakukan. Ciri-ciri strategi yaitu (1) selalu menfokuskan perhatian pada tujuan yang ingin dicapai, (2) strategi memusatkan perhatian pada gerak dan langkah yang harus dilakukan untuk mencapai tujuan tersebut, (3) sangat memperhatikan analisis gerak, analisis aksi dan analisis dinamik, (4) sangat memperhitungkan faktor lingkungan baik eksternal maupun internal, (5) strategi sangat mempertimbangkan faktor waktu, (6) berusaha menemukan masalah yang dihadapi, kemudian mengadakan analisis mengenai berbagai kemungkinan yang akan timbul serta menetapkan pilihan-pilihan dan langkah dalam mencapai tujuan, (7) memusatkan perhatian pada kekuatan yang dimiliki. ${ }^{12}$

Sanjaya membagi hal yang perlu diperhatikan dalam strategi yaitu; (1) strategi merupakan rencana tindakan termasuk penggunaan metode dan pemanfaatan berbagai sumber daya atau kekuatan. Dengan demikian strategi merupakan proses penyusunan rencana kerja, belum sampai pada tindakan. (2). Strategi disusun untuk mencapai tujuan tertentu. Artinya, arah dari sebuah keputusan penyusunan strategi adalah pencapaian tujuan. ${ }^{13}$ Saleh menawarkan beberapa faktor yang dipertimbangkan agar strategi itu benar-benar dapat mengantarkan organisasi ke arah tujuan, yaitu pertama, ideology; kedua, visi; ketiga, misi; keempat, usaha atau pola tugas; kelima, lingkungan, baik eksternal maupun internal. ${ }^{14}$

Definisi dakwah terbagi atas dua yaitu dakwah menurut bahasa dan dakwah menurut Istilah. Dari segi bahasa, kata dakwah berasal dari bahasa Arab "da'wah" yang huruf dal, 'ain, dan wawu. Ketiga huruf asal ini membentuk beberapa kata dengan ragam makna seperti memanggil, mengundang, minta tolong, meminta, memohon, menamakan, menyuruh datang, mendorong, menyebabkan, mendatangkan, mendoakan, menangisi dan meratapi. ${ }^{15}$ Menurut istilah terma dakwah dalam Al-Qur'an dipergunakan untuk pengertian yang lebih luas dari pemaknaan dakwah yang dipergunakan oleh masyarakat dakwah. Dalam ilmu dakwah, istilah dakwah cenderung dipakai untuk menunjuk proses dakwah yang berpihak 
pada ajaran Islam. Lebih lanjut bahwa pengertian keagamaan ini dakwah memasukkan aktifitas tabligh (penyiaran), tatbiq (penerapan/pengamalan) dan tandhim (pengelolaan). ${ }^{16}$ Sedangkan Aziz mendefinisikan dakwah merupakan proses peningkatan iman dalam diri manusia sesuai syariat Islam. "Proses" menunjukkan kegiatan yang terus-menerus, berkesinambungan, dan bertahap. Peningkatan adalah perubahan kualitas yang positif; dari buruk menjadi baik, atau dari baik menjadi lebih baik. Peningkatan iman termanifestasi dalam peningkatan pemahaman, kesadaran, dan perbuatan. ${ }^{17}$

Dakwah merupakan ajakan manusia kepada kebenaran (jalan Allah SWT), rujukan pelaksanaannya mengacu pada penegasan al-Qur'an surah An-Nahl:125, "Serulah (manusia) kepada jalan Tuhan-mu dengan hikmah dan pelajaran yang baik dan bantahlah mereka dengan cara yang baik, (QS. An-Nahl [16]:125). Oleh karena itu tujuan dakwah dapat dibagi menjadi dua macam, yaitu tujuan utama (umum) dan tujuan khusus (perantara). Tujuan utama merupakan garis pokok yang menjadi arah semua kegiatan dakwah, yaitu perubahan sikap dan prilaku mitra dakwah sesuai dengan ajaran Islam. Tujuan umum ini tidak dicapai sekaligus karena mengubah sikap dan prilaku seseorang bukan pekerjaan sederhana. Oleh karena itu perlu tahap-tahap pencapaian. ${ }^{18}$

Merujuk ayat di atas sebagai landasan dakwah maka terdapat pendekatan dakwah yakni, (1) metode pendekatan ilmiah (bil al-hikmah), dakwah bi al-hikmah berarti dakwah bijak yakni selalu memperhatikan suasana, situasi dan kondisi mad'u. Menggunakan metode yang relevan dan realistis sebagaimana tantangan dan kebutuhan, dengan memperhatikan kadar pemikiran dan intelektual, suasana psikologis, serta social kultural mad'u. ${ }^{19}$ (2) Metode dakwah al-mau'idzah al-hasanah, pendekatan nasehat secara santun kepada kaum awam. Mau'idzah al-hasanah, maksudnya adalah memberikan nasehat kepada orang lain, yaitu petunjuk-petunjuk ke arah kebaikan dengan bahasa yang baik, ${ }^{20}$ (3) metode dakwah mujadalah billati hiya ahsan, yakni pendekatan dialog dan logis kepada kalangan yang sejak semula sudah menolak. ${ }^{21}$

Menurut Amin secara umum dakwah Islam dikategorikan ke dalam tiga macam yaitu:(1) dakwah bi al-lisan, yaitu dakwah yang dilaksanakan melalui lisan, yang dilakukan antara lain dengan ceramah-ceramah, khutbah, diskusi, nasehat dan lain-lain.(2) Dakwah bi al-hal, yakni dakwah dengan perbuatan nyata meliputi keteladanan, misalnya dengan tindakan 
amal karya nyata. (3) Dakwah bi al-qalam, yakni dakwah melalui tulisan yang dilakukan dengan keahlian menulis di surat kabar, majalah, buku maupun internet. ${ }^{22}$

Aziz membagi strategi dakwah yakni strategi tilawah, strategi tazkiyah dan strategi ta'lim. (1) Strategi Tilawah (membacakan ayat-ayat Allah SWT). Strategi ini mitra dakwah diminta mendengarkan penjelasan pendakwah atau mitra dakwah membaca sendiri pesan yang ditulis oleh pendakwah. Demikian ini merupakan transfer pesan dakwah dengan lisan dan tulisan. Strategi tilawah bergerak lebih banyak pada ranah kognitif (pemikiran) dan transformasinya melalui indra pendengaran (al-sam') dan indra penglihatan (al-absar) serta ditambah akal yang sehat (al-af-idah). (2) Strategi Tazkiyah (menyucikan jiwa). Strategi tazkiyah melalui apek kejiwaan. Sasaran strategi ini bukan pada jiwa yang bersih tetapi jiwa yang kotor. (3) Strategi Ta'lim. Metode ini dapat dilakukan pada mitra dakwah yang tetap, dengan kurikulum yang telah dirancang, dilakukan secara bertahap serta memiliki target dan tujuan tertentu. Jika menengok strategi pendekatan yang telah dilakukan oleh Nabi Muhammad SAW, ${ }^{23}$ terdapat dua strategi pendekatan dakwah, yaitu (a) pendekatan struktural, dakwah melalui jalur struktur formal misalnya melalui pemerintahan. (b) Pendekatan kultural, pengembangan dakwah melalui jalur kultural nonformal, misalnya melalui pengembangan masyarakat, kebudayaan, sosial dan bentuk nonformal lainnya. ${ }^{24}$

Konsep dakwah Muhammadiyah selain dakwah Jamaah yang telah dirumuskan pada Muktamar Muhammadiyah ke-38 tahun 1971 di Makassar juga dakwah kultural yang secara formal digagas dan menjadi keputusan sidang Tanwir di Denpasar Bali tahun 2002 lalu telah mendefinisikan konsep dakwah yang lebih terfokus pada penyadaran iman dengan memperhatikan berbagai pendekatan dan tahapan dalam berbagai unit sosial. Konsep dan manifestasi dakwah ini merangkum dimensi kerisalahan, kerahmatan, dan kesejarahan dalam berbagai bidang kehidupan manusia. Dakwah Muhammadiyah menurut Majelis Tabligh dan Dakwah Khusus PP Muhammadiyah sebagai upaya menjadikan Islam agama rahmatanlil-'alamin idealnya menyentuh semua lapisan maupun kelompok masyarakat yang ada.

Dakwah kultural adalah aktivitas dakwah yang menekankan pendekatan Islam-kultural. Islam kultural adalah salah satu pendekatan yang berusaha meninjau kembali kaitan doktrinal yang formal antara Islam dan politik 
atau Islam dan Negara. ${ }^{25}$ Terdapat dua arah pemikiran dalam masalah dakwah bercorak kultural. Pertama, dakwah kultural berarti dakwah yang diaktualisasikan dalam kegiatan tabligh dengan memanfaatkan bentukbentuk kegiatan yang tergolong kegiatan kultural. Hal ini berarti kegiatan kultural sebagai metode. Kedua, dakwah kultural berarti dakwah yang diaktualisasikan dalam kegiatan tabligh dimaksudkan untuk menghasilkan kultur baru yang bernuansa Islami. Arah kedua ini berarti kegiatan kultural sebagai substansi. Kedua arah ini harus dipilih, apakah salah satu di antaranya atau kedua-duanya. ${ }^{26}$

Setidaknya ada lima program kultural, yaitu mengembalikan dan mengembangkan (1) tradisi lokal, (2) tradisi egalitarian, (3) tradisi berbudaya, (4) tradisi ilmiah, (5) tradisi cosmopolitan. Berdasarkan konsep dan fokus pada upaya penyadaran iman dalam dakwah kultural, tidak lepas dari berbagai strategi pelaksanaan dan pendekatan. Pada dasarnya strategi dakwah adalah metode, siasat, taktik, atau manuver yang dipergunakan dalam aktivitas (kegiatan) dakwah. ${ }^{27}$ Strategi dakwah adalah perencanaan yang berisi rangkaian kegiatan yang didesain untuk mencapai tujuan dakwah tertentu. ${ }^{28} \mathrm{~S}$

\section{HASIL PENELITIAN DAN PEMBAHASAN}

\section{Sejarah dan Profil Masyarakat Adat Karampuang}

Karampuang dalam sejarah masa lalunya diawali oleh kehadiran sosok To Manurung (Manurung'e ri Karampulue), kata "Karampulue" pada akhirnya dikenal dengan sebutan "Karampuang" yang menjadi cikal bakal adat Karampuang. Riwayat lain menurut Muhannis, penamaan selanjutnya adalah perpaduan antara karaeng dan puang akibat dijadikannya lokasi tersebut sebagai tempat pertemuan antara orang-orang Gowa yang bergelar Karaeng dan orang-orang Bone yang bergelar Puang sehingga disebutlah Karampuang. ${ }^{29}$

Sejak pra Islam masyarakat Bugis mempercayai istilah "To Manurung"yang berarti seseorang yang dipersonifikasikan kehadirannya yang secara tiba-tiba ada ditengah masyarakat. To Manurung akhirnya diangkat menjadi pemimpin oleh warga serta membuka lahan pertanian untuk warga, namun tidak lama To Manurung pertama ini pun menghilang dengan meninggalkan benda arajang (pusaka) yang masih tersimpan di rumah adat Karampuang. Selanjutnya diganti dengan munculnya tujuh To Manurung baru yang memimpin wilayah-wilayah di sekitarnya. Riwayat 


\section{4 s samen}

kehadiran, wasiat, berserta menghilangnya To Manurung terhimpun dalam kitab Lontara yang dipercaya masyarakat Karampuang sebagai penggerak dan pemicu semangat kehidupan bermasyarakat. Masyarakat adat ini tetap patuh pada aturan warisan leluhur yang terangkum dalam pappaseng (pesan leluhur) dan dijadikan sebagai sumber hukum. ${ }^{30}$

Karampuang masuk dalam wilayah definitif desa Tompobulu, kec. Bulupoddo, kab. Sinjai dengan dimensi alam perbukitan dan ketinggian sekitar 618 meter di atas permukaan laut, curah hujan $75 \mathrm{~mm}$ dan suhu udara rata-rata $23^{\circ} \mathrm{C}$. Data wilayah adat Karampuang kab.Sinjai menurut laporan hasil pemetaan partisipatif wilayah adat (AMAN Sinjai, 2015) seluas 2.554,95 hektar sebagian besar mata pencaharian penduduknya adalah bertani dan berkebun, data populasi masyarakat adat Karampuang sebanyak 3285 orang dengan jumlah laki-laki sebanyak 1660 dan jumlah perempuan sebanyak 1625 orang, sebanyak 823 jumlah KK. ${ }^{31}$

Selain pemerintahan formal konsepsi adat dalam Pappaseng dan Lontara menjadi bagian penting kehidupan masyarakat termasuk berkaitan tradisi ritual sehingga konsepsi pemerintahan dalam wilayah adat Karampuang bersifat komplementer, integral dan tradisional bahkan pola adat lebih dominan. Di wilayah adat ini terdapat beberapa peninggalan arkeologis yang terbuat dari batu, terdapat dua rumah adat yang menjadi simbol pembagian tugas dan fungsi masing-masing struktur adat sekaligus tempat pertemuan dalam mengambil berbagai keputusan adat.

Menurut Said adat adalah aturan-aturan tentang kehidupan manusia yang disepakati penduduk dalam suatu daerah tertentu untuk mengatur tingkah laku anggotanya sebagai kelompok sosial. ${ }^{32}$ Masyarakat adat Karampuang memiliki pemimpin yang masih tetap menjalankan peran dan fungsinya sesuai dengan Pappaseng (pesan leluhur) yang diwariskan leluhurnya. Komunitas ini memiliki struktur pemerintahan yang mirip dengan Trias Politica yang dikenal dalam pemerintahan modern dan dipakai dibanyak negara di dunia. Sebagai legislatif mereka memiliki empat anggota dewan adat sebagai perwakilan masyarakat yang disebut dengan Ade' Eppa' yakni Arung, Ade', Sanro dan Guru. Arung, Ade' (gella), Guru harus dijabat oleh laki-laki, sedangkan Sanro harus dijabat perempuan. Keempatnya dijuluki Eppa alliri teteppo'na wanuae (empat tiang penyangga keutuhan kampung). Kedudukan mereka selalu dianalogikan dengan ungkapan api tettong arung, tana tudang ade', angin rekko sanro, wae suju' guru atau ibarat tegaknya api adalah raja, duduknya adalah tanah 
Ade', rukuknya adalah angin sanro adalah dukun dan sujudnya air adalah guru. Sebagai eksekutif atau yang menjalankan roda pemerintahan mereka mengenal Pakkatenni Ade' atau Pareha Ade', yang terdiri dari To Matoa sebagai pemimpin tertinggi dibantu oleh tiga orang pembantu semacam menteri yakni Gella, Sanro, Guru dimana ketiganya dibantu oleh Bali Tudangeng. ${ }^{33}$

Adapun fungsi dan tugas masing-masing Ade' Eppa'e beserta pembantu adat tersebut yakni: (1) To Matoa (Arung) sebagai pucuk pimpinan adat, tugas utama Arung adalah sebagai pengendali utama dalam pemerintahan adat Karampuang. (2) Gella', tugas utama Gella adalah menangani perihal pertanian, perkebunan dan kehutanan serta pekerjaan yang bersifat umum lainnya jadwal pesta adat dan penanaman benih pada lahan pertanian.(3) Sanro, berperan pokok menangani masalah (ritual) lainnya, kesejahteraan dan kesehatan masyarakat. Peran sosial ini mengakomodasi pelayanan kesehatan yang tidak dijangkau oleh tenaga kesehatan desa. Kata "sanro' pada umumnya dikenal masyarakat Bugis sebagai orang yang mampu memimpin ritual maupun menangani kesehatan (pengobatan) dengan cara tradisional. (4) Guru, tugas Guru menangani keagamaan, budaya, pendidikan dan kepemudaan masyarakat adat Karampuang. Adapun Bali Tudangeng semacam dirjen di suatu kementerian, memiliki peran mendampingi tugas pembantu adat. Gella, dibantu oleh Uragi, Pallontara. Sanro, dibantu oleh Paggenrang, Pinati, Pappajo.Guru, dibantu oleh Bilala (bilal), Katte (khatib), doja dll. Peran To Matoa dan Gella begitu padat maka keduanya juga dibantu oleh Ana Malomo atau semacam sekertaris atau ajudan tetapi tidak boleh menjadi wakil dalam urusan adat. Jika dalam urusan adat hanya boleh dihadiri oleh To Matoadan Gella. ${ }^{34}$

Struktur dan pembagian tugas tersebut menunjukkan hubungan kerja dan peran masing-masing dalam melaksanakan tugas jabatan. Setiap pemangku adat bertanggung jawab dalam suatu kelompok urusan. Unsur tertinggi pemangku adat yakni Arung (To Matoa) dan Gella sebagai pengendali pemerintahan adat maka kepadanya terpusat kebijakan adat, menjadi otoritas tradisional termasuk kebijakan yang berhubungan pelaksanaan ritual besar. Sedangkan dalam urusan ritual skala kecil merupakan peranan Sanro sebagai pengendali. Sedangkan Guru memegang kendali SDM disamping peran serta Bali Tudangeng. Kebijakan politik dan pelaksanaan tugas mereka saling berhubungan satu sama lain untuk 
melahirkan keputusan yang dapat bermuara pada kemaslahan adat maupun masyarakat pendukung.

\section{Kehidupan Pra hingga Masuknya Islam, Keberagamaan dan Budaya Masyarakat Adat Karampuang.}

Sebelum perkembangan agama Islam di wilayah Kabupaten Sinjai pada umumnya dan Karampuang khususnya kondisi sosial budaya dan politik sangat dipengaruhi oleh eksistensi kerajaan-kerajaan yang tergabung dalam federasi Tellulimpoe di daerah pesisir seperti Kerajaan Tondong, Kerajaan Bulo-Bulo dan Kerajaan Lamatti demikian pula Kerajaan Pitulimpoe yang berada di dataran tinggi adalah gabungan Kerajaan Turungeng, Manimpahoi, Terasa, Pao, Manipi, Suka dan Bala Suka. ${ }^{35}$

Kehidupan sosial dan kepercayaan masyarakat Sinjai, penulis meminjam kerangka yang digunakan Muhannis untuk memberikan gambaran tentang kepercayaan lokal adat Karampuang. Menurutnya mereka memiliki kepercayaan kepada Puang Lohe atau sebutan Pallohe yang berarti maha besar atau berkuasa. Pallohe dibantu oleh Cinna Bolong yang menguasai daratan, Cinna Gau'e yang menguasai air dan pesisir, Dewata Ri Toli yang menguasai hutan dan gunung dan Sangiaserri yang menguasai padi. Bentuk kepatuhan kepadanya adalah dengan melakukan ritual kuno seperti Marumatang yang dimaksudkan untuk mengundang roh-roh leluhur untuk datang menyaksikan aktivitas mereka sebagai manifestasi akan kecintaannya pada leluhur. ${ }^{36}$

Pendapat tersebut serta beberapa fakta menunjukkan hingga saat ini sebagian masyarakat Sinjai khususnya di perdesaan masih menganut kepercayaan nenek moyang serta meyakini keberadaan roh halus pada tempat-tempat tertentu. Kondisi ini mengindikasikan jika pra Islam masyarakat Karampuang mempraktekkan ritual sebagai simbol totalitas pengakuan pada Puang Lohe. Hingga belum satu pun agama samawi yang menggeser bentuk kepercayaan dan ritual ini hingga datangnya Islam.

Jejak masuknya agama Islam kewilayah Kabupaten Sinjai tidak lepas dari peranan ulama di Sulawesi Selatan. Menurut Mattulada ada tiga ulama besar yang sangat terkenal dan berjasa dalam penyebaran Islam di Sulawesi Selatan yaitu Abdul Khatib Tunggal, Sulaiman Khatib Sulung dan Abdul Jawad Khatib Bungsu, atau lebih dikenal Datuk Ri Bandang, Datuk 
Pattimang dan Datuk ri Tiro. ${ }^{37}$ Ketiganya memiliki pembagian kerja dalam menyebarkan Islam di berbagai wilayah Sulawesi Selatan, daerah Gowa dan Makassar oleh Dato' ri Bandang dengan pendekatan syariat Islam, daerah Luwu dan sekitarnya oleh Datu' Pattimang dengan pendekatan tauhid (kepercayaan lama Sure' I Lagaligo) sedangkan daerah Bulukumba dan sekitarnya adalah Datu' ri Tiro dengan pendekatan tasawuf. Disamping peranan Syeh Yusuf Al-Makassari sebagai ulama lokal turut mengambil peran signifikan. Masuknya agama Islam di Sinjai diperkirakan tahun 1907. Terdapat beberapa kronologi masuknya menurut sejarawan di antaranya Basrah Gising mengemukakan bahwa penerimaan Islam di Sinjai dikatakan berjalan lancar karena adanya komunikasi antara salah satu penguasa Sinjai masa pemerintahan Arung Bulo-Bulo VII dengan Raja Gowa.Menurut Hamid keberadaan daerah Tiro yang relatif dekat dengan daerah Sinjai menjadi sebab informasi adanya aktifitas penyiaran Islam tersebut cepat sampai ke Sinjai. Pasca kerajaan Gowa menerima Islam secara resmi sebagai agama kerajaan, maka dikirimlah muballigh bernama To Mappe Daeng Situncu di Kerajaan Turungeng (Pitu Limpoe). ${ }^{38}$

Proses tersebut menunjukkan masuknya agama Islam dilakukan dengan pendekatan struktural (pemerintahan), pendekatan syariat Islam maupun pendekatan dakwah ulama (pendekatan tasawuf) dengan persuasive educative secara damai baik antar kerajaan maupun raja-raja pada rakyatnya. Strategi penyebaran Islam secara terbuka dengan transformasi adat disesuaikan dengan konsepsi pangadereng (hal ikhwal tentang adat istiadat) sehingga agama Islam dengan cepat diterima secara terbuka. Hal ini berkaitan yang dikemukakan Nashir bahwa kehadiran Islam di Sulawesi Selatan merupakan titik sejarah baru yang mengubah tatanan masyarakat terutama dalam kehidupan politik kerajaan dan sistem religi. ${ }^{39}$

Pada umumnya komunitas adat dipandang sebagai komunal tradisional baik dari sistem kepercayaan, pemerintahan, bahasa maupun pola hidup yang berbeda dengan masyarakat pada umumnya. Warga Karampuang menganut ajaran agama Islam sebagaimana masyarakat sekitarnya terwujud dari pelaksanaan ibadah seperti shalat lima waktu, ibadah jum'at, puasa ramadhan, zakat serta aktivitas pendidikan majelis taklim, pengajian, TK/TPA maupun aktivitas pendidikan di lembaga formal disekitar Karampuang bahkan ketingkat perguruan tinggi. Meskipun praktek keagamaan (ajaran agama Islam) pada kehidupan sehari-hari mereka bersanding erat dengan sistem leluhur budaya tradisional seperti ritual- 
ritual adat menunjukkan indikasi multi keyakinan secara fundamental dimana aktivitas agama Islam dijalankan sedang konsepsi-konsepsi adat yang bersifat ritual adat pun dilaksanakan bahkan lebih berperan dan mendominasi pola-pola kehidupan masyarakat mereka.

\section{Sistem Kepercayaan dalam Upacara Adat Mappogau Hanua}

Masyarakat adat Karampuang memiliki upacara adat yang terbagi ke dalam empat kategori besar dengan masing-masing penanggung jawab. Dalam pesan leluhurnya ada ungkapan yang mengatakan bahwa "Mappogau Hanuai Arungnge, Mabbissa Lompui Gella'E, Makkaharui Sanroe, Mattula Balai Guru'E". Pembagian kategori ini menandakan masing-masing pemangku adat memiliki tugas dan kewenangan yang berhubungan dengan ritual-ritual tertentu. Di antara ritual terbesar yakni "Mappogau Hanuai Arungnge" sebagai acara adat (ade' eppa'E) namun penanggungjawab ritual ada pada Arung (To Matoa) dalam hal berhubungan dengan ritual yang sifatnya sakral yakni kepada leluhurnya yang suci (puang lohe) sehingga prosesi ritual adat ini memiliki dimensi ganda serta bermakna luas dan mendalam. Manifestasi kepercayaan dalam pelaksanaan ritual Mappogau Hanuaadat Karampuang menekankan beberapa rangkaian yaitu: ${ }^{40}$

Mabbahang, merupakan rapat internal yang membicarakan tentang waktu dan pelaksanaan acara adat maupun teknis pembagian tugas, dihadiri oleh unsur adat dengan melibatkan pemerintah desa serta dilakukan selama tiga hari. Penentuan waktu (hari) pelaksanaan disebut mattanra esso seperti hari ke 7 atau hari ke 9 antara hari Senin dan Kamis sesuai perhitungan adat. Dalam hal pembagian tugas adat maka unsur adat memiliki peran inti memimpin ritual-ritual. Inti kegiatan ini dilakukan jika telah usai musim panen padi sawah-sawah adat dan sawah penduduk. Oleh karena itu sebelum dilakukan upacara besar maka telah tersedia hasil panen kemudian diputuskanlah acara Mabbahang.

Mappaota, Tahap selanjutnya dilakukan Mappaota yang merupakan ritual memohon restu untuk melakukan upacara besar dengan mengunjungi objek-objek suci dan keramat seperti bukit, lembah, sungai dan batu-batu besar disekitar kawasan adat Karampuang yang dipimpin oleh Sanro dengan membawa sesajian dimaksudkan mengenang leluhurnya yang bersemayang ditempat-tempat tersebut dan telah memberkati kehidupan dengan hasil pertanian yang subur. Mabbaja-baja 
(mappasyakka), yakni kegiatan membersihkan selama tiga hari dari masingmasing lingkungan rumah, jalanan, perkantoran, tempat ibadah terlebih utama kawasan upacara adat yang diharapkan kegiatan upacara menjadi lebih suci. Hal ini untuk memperindah kawasan adat yang akan dihadiri oleh berbagai kalangan masyarakat umum pada puncak ritual Mappogau Hanua.

Menre ri bulu' (mendaki ke pucak bukit) dipimpin oleh Sanro dan To Matoa, dilakukan saat tiba waktu dhuhur dengan ketersediaan olahan makanan dari hasil pertanian maupun potongan hewan ternak yang terlebih dahulu dilakukan proses pemberkahan ritual Mattuli oleh Sanro dengan maksud menyambut kehadiran padi. Dalam kegiatan ini adalah peringatan rangkaian kematian yakni (1) Mallohong (meletakkan kain putih) diatas batu untuk melepaskan hewan ternak, (2) Mallayang mengenang kematian dengan (melepaskan nazar/hajat/niat), dimana keyakinan masyarakat bahwa ruh menghilang sebagaimana menghilangnya para To Manurung.(3) Digattung, menggantung kain putih sebagai simbol kematian kedua yaitu digattung,(4) Ditunu, prosesi ini dilakukan dengan membakar hasil bumi sebagai peringatan jenis kematian tahap ketiga yaitu ditunu. Selain itu dilakukan pula ritual persembahan pada penjaga hutan (cinna bolongnge). Dilain tempat Pinati melakukan ritual di rumah adat (mappaleppe ribola) dengan sesajian dan dipersembahkan dipanoo' diwae pada penguasa air (sungai) atau disebut cinna gaue dipimpin oleh Sanro, (5) Dibalaburu'pada tahap lain ritual balaburu juga dilakukan untuk memperingati dan mengenang prosesi penguburan menumpuk mayat (satu lubang kuburan), (6) Masseddi-Seddi, pada tahap akhir ini merupakan peringatan kematian tingkat akhir dimana manusia dikubur satu persatu. Inti rangkaian tersebut adalah mengenang berbagai bentuk prosesi kematian para leluhur selama ratusan tahun dalam kepercayaan mereka. Bentuk ritual adat menre ri bulu diakhiri dengan manre ade' (makan bersama) pada malam hari oleh penghulu adat dan para pejabat pemerintahan yang turut hadir mengikuti upacara adat Mappogau Hanua.

Mabbali Sumange, yakni sub ritual adat di mana masyarakat setempat menyiapkan kue tradisional yang dibuat secara khusus, serta menyiapkan dedaunan (obat) dari berbagai jenis guna pembuatan dan pengobatan bagi warga pendukung kebudayaan adat Karampuang. Selain itu ritual dilakukan pula mabbacce (pemberkatan) oleh Sanro kepada warga dan anak-anak dengan cara memberi tanda pada dahi yang dimaksudkan agar 
dijauhkan dari penyakit serta sebagai simbol inisiasi anggota adat Karampuang. Mabbali Sumange' diakhiri di pagi hari sekaligus pertanda warga adat telah siap menanami lahan pertanian dan perkebunannya. Malling, merupakan ikhwal berpantang (larangan) dimulai tiga hari setelah mabbali sumange'. Larangan bagi warga memotong hewan (mappaccera), membuat sayuran dari daun-daunan serta melakukan ritual sendiri-sendiri. Setelah malling kembali dilakukan mabbahang guna mengevaluasi rangkaian upacara Mappogau Hanua serta rencana adat selanjutnya.

Rangkaian upacara adat tersebut bersifat wajib sebab pelaksanaannya tidak akan utuh dan sempurna apabila terdapat rangkaian terlewatkan. Inti pelaksanaan Mappogau Hanua adalah pemujaan leluhur menggunakan media tinggalan megalitik dan persembahan sesaji. Pemberian sesaji sebagai bentuk pengabdian manusia terhadap leluhurnya yang dipuja dan mengandung arti yang mendasar yaitu sebagai simbol pengukuhan hubungan emosional antara warga dan leluhurnya. Hubungan itu begitu penting dalam pikiran mereka agar kesuburan tanah tetap terjaga dalam melaksanakan kehidupan kepetaniannya. ${ }^{41}$

Sebagai Paseng Ri Karampuang (pesan adat Karampuang) terdapat pantangan bagi masyarakat apabila tidak mengadakan ritual adat Mappogau Hanua, menurut Mangga' "wanuae de'ga decengna, timo' temmatuttu' materau'kkajue, na lele sai'E", 42 "kampung ini tidak akan kedamaian dan ketentraman, kemarau panjang dapat terjadi serta menyebarnya penyakit yang diderita warga". Kepatuhan mereka dalam menjalankan ritual ini adalah adanya kecemasan beban hidup apabila alpa mengadakan ritual. Hal ini memungkinkan karena Karampuang sendiri memiliki lahan garapan yang terbatas dengan kesuburan tanah yang berbeda-beda. Sumber daya dan keterampilan menggiring mereka menghindari hal-hal yang sifatnya luar biasa sehingga salah satu cara untuk bersahabat dengan alam dan hal yang gaib adalah mengadakan ritual. ${ }^{43}$

Sejarah panjang tradisi Mappogau Hanua adalah aktivitas budaya masyarakat sejak pra Islam atau kepercayaan bermotif animisme-dinamisme dan masih bertahan mengingat akar kepercayaan ini berkaitan dengan dimensi kepercayaan abstraksi kepada leluhur (Puang Lohe) dengan ciri pemujaan (ascentor worship), ritual adat suciyang sifatnya multidimensi menghubungkan mereka dengan leluhur (vertical forefathers) sehingga membangkitkan kekuatan (power life) sepanjang kehidupan dalam adat mereka. 
Mappogau Hanua sebagai suatu sistem religi dianggap sebagai bagian penting dalam hidup dan keyakinan masyarakat Karampuang. Maka masyarakat Karampuang dapat dikatakan sebagai bagian dari penganut kepercayaan Patuntung di Kab. Sinjai, hal ini sebagaimana disebutkan oleh Renre bahwa Patuntung adalah suatu sistem religi karena mereka bicara tentang ketuhanan, kemasyarakatan, alam dan kegiatan-kegiatan kehidupan mereka selalu dihubungkan dengan paham kepercyaan mereka. ${ }^{44}$

\section{Fungsi dan Tujuan Upacara Adat Mappogau Hanua}

Ritual Mappogau Hanua memiliki fungsi menyatukan keinginan ritual hajat masyarakat adat dan pendukungnya dalam bentuk event kemasyarakatan. Mendorong kekuatan dalam bentuk kebersamaan antar masyarakat pendukung dalam satu kepentingan ritual. Sehingga tujuannya adalah lebih dari sekedar memperkuat silaturahim. Mappogau Hanua juga mengisyaratkan sebagai manifestasi rasa syukur kepada Sang khalik (Tuhan Yang Maha Esa), bentuk komunikasi dan relasi individu dengan sang kuasa yang berefek pada kedamaian dan ketenteraman hidup sehingga esensi ritual ini bermakna kesyukuran.

Secara antropologis event akbar Mappogau Hanuayang meriah, pelaksanaannya telah dijadikan sebagai agenda nasional dan tahunan Pemerintah Daerah Kab. Sinjai guna ajang mengenalkan budaya lokal. Mappogau Hanua dilaksanakan tiap tahunnya oleh warga maupun pendukung masyarakat adat tiap bulan November tahun berjalan, terlaksana dalam waktu selama satu minggu dan dipusatkan dalam kawasan adat Karampuang, khususnya di dua rumah adat yang biasa disebut Lao Pole yang dijadikan sebagai pusat aktivitas adat dan sosial budaya dan keagamaan.

\section{Nilai-Nilai dalam Upacara Adat Mappogau Hanua}

Terdapat nilai-nilai penting dalam pelaksanaan upacara adat Mappogau Hanuayaitu:45 (1) nilai solidaritas/persatuan. Pelaksanaan kegiatan yang memerlukan waktu, pembiayaan dan tenaga yang besar menjadikan kegiatan sebagai kegiatan bersama di mana kecenderungan warga bahu membahu dengan kesadaran menumbuhkan solidaritas sosial yang harmonis menyukseskan acaranya. (2) Nilai filosofis dan religi, sebagai 
suatu kawasan sakral kawasannya dianggap sebagai mikro kosmos yang wajib dijaga. (3) Nilai pelestarian alam, dalam menjalankan tradisinya, mereka harus tetap dekat dan bersahabat dengan alam sekitarnya. (4) Nilai seni, nilai-nilai seni sangat menonjol sehingga sekaligus berfungsi sebagai hiburan. Nila-nilai di atas merupakan karakter kebudayaan masyarakat Karampuang dalam upacara adatnya dengan menampilkan tradisi yang khas dan dinamis tetap tumbuh dan dipertahankan oleh individu masyarakatnya. Tergambar jelas dalam kehidupan keseharian masyarakat Karampuang seperti adanya sama turu' (berpartisipasi), asamaturuseng (kesepakatan), sama onro (persamaan), makkeguna (efektif dan efisien), serta pakkita mabela (visi strategis). Akuntabilitas masyarakat Karampuang terdiri atas transparansi mempunyai tiga landasan yakni lempu' (jujur), tongeng (kebenaran), dan getteng (teguh).

\section{Strategi Dakwah Kultural Muhammadiyah dalam Upacara Adat Mappogau Hanua.}

Sebelum dikemukakan strategi dakwah kultural Muhammadiyah kiranya penting melacak jejak dakwah agama Islam di Karampuang sebagai suatu titik tolak strategi dakwah ini. Dakwah Islam telah diawali sejak penyebar agama Islam masuk ke wilayah tersebut dalam sejarahnya masyarakat Karampuang menerima dakwah, pernah merasakan trauma sejarah (sakit hati) apabila ada yang bicara soal agama yang dapat mengeser tradisi kepercayaan leluhur mereka, disebabkan oleh gerakan separatisme DI/TII merusak simbol adat. ${ }^{46}$ Mangga'menuturkan jika masyarakat menjamu kehadiran para pendatang tentara Gurillae (gerilyawan) sebelum meninggalkan kampung mereka membakar rumah adat dan isinya, merusak benda-benda keramat (arajang), bertahun-tahun kemudian baru dapat dibangun kembali. ${ }^{47}$

Kasus sejarah ini kemudian menimbulkan luka mendalam dan traumatis masyarakat Karampuang mengingat aktivitas adat yang dianggap bertentangan dengan ajaran agama Islam oleh gerakan DI/TII yang menerapkan syariat agama sebagai dasar negara dan hukum Islam dalam pola-pola kehidupan masyarakat khususnya di wilayah kekuasaan de-facto DI/TII di Sinjai. Dari hal ini kemudian mengakibatkan kegiatan dakwah mengalami kemandekan karena kondisi politik negara yang tidak stabil, bahkan sampai saat ini Muhammadiyah belum melakukan dakwah secara 
kelembagaan, hanya dilakukan perorangan sebab jika dipaksakan purifikasi akan mudah mendapatkan sanksi sosial.

Jikamerujuk pandangan sejarah konsepsi adat ini maka tradisi adat yang telah direkonstruksi dan disesuaikan ajaran Islam dapat ditemukan peringatan jenis-jenis kematian manusia yang berlansung sejak lama. Rangkaian jenis kematian dalam kepercayaan adat sebagaimana disebutkan diawal yakni pada kegiatan inti Menre ri bulu', pada jenis kematian kelima dibalaburu (dikubur satu lubang kuburan) ini mengalami rekonstruksi saat datangnya ajaran Islam untuk menguburkan mayat satu persatu tiap liang lahat (massedi-seddi) sehingga jenis kematian masseddi-seddi merupakan hasil rekonstruksi ajaran Islam.

Seiring perkembangan zaman adanya perubahan dalam prosesi adat demikian menandakan masyarakat telah menerima dakwah ajaran Islam. Sejak agama Islam terintegrasi kedalam Ade Eppa'eyakni sejak posisi Guru tergabung dalam struktur adat dimana peran khusus Guruterkait kebijakan keagamaan dan pendidikan khususnya pengajaran Islam. Di antara kebijakan guru terkait simbol keagamaan terlihat dari pembangunan rumah yang bernuangsa Islami khususnya rumah adat yang hadir dari generasi ketiga Arung, secara filosofis pembangunannya telah disesuikan dengan ajaran agama Islam. Simbolis 5 tiang berdiri untuk lebar rumah dimaksudkan untuk menandakan 5 rukun Islam, 6 tiang untuk panjang rumah dimaksudkan untuk menandakan rukun iman, jika dikali sejumlah tiang tersebut berjumlah 30 yang menandakan 30 juz Al-Qur'an. 5 petak dalam rumah dimaksukan untuk menandakan 5 shalat wajib dalam Islam serta terdapat tempat khutbah (mimbar) di dalam rumah adat. Kedua rumah adat tak hanya digunakan sebagai pusat kebudayan dan legitimasi pengambilan keputusan adat namun lebih pada aktivitas keagamaan (Islam) seperti pelaksanaan ibadah tarwih di bulan ramadhan yang dilakukan secara bergantian di antara kedua rumah adat dengan masjid kawasan adat Karampuang, pelaksanaan shalat idul fitri dan idul adha, serta dijadikan pusat pembagian zakat fitrah.

Berdasarkan data empiris diatas maka strategi dakwah kultural Muhammadiyah pada upacara adat Mappogau Hanua di masyarakat adat Karampuang dikemukakan sebagai berikut:

\section{a. Strategi Partisipatif dan Kekeluargaan}

Kulturalisasi dakwah di antara kader Muhammadiyah yang banyak mengambil peran dalam pelaksanaan ritual Mappogau Hanua ialah 
Drs.Muhannis, strategi dan pendekatan yang dilakukan Muhannis melalui partisipatif dan kekeluargaan dengan melibatkan diri dalam berbagai kegiatan-kegiatan adat Karampuang selama waktu kurang lebih 20 tahun. Pendekatan ini dilakukan Muhannis untuk meninjau aspek budaya masyarakat dengan terlibat secara lansung. Selain sebagai budayawan dan peneliti sosial juga berhasil melakukan rekonstruksi sederhana dalam tradisi adat Karampuang yang didasarkan pada pandangan normatif. Langkah yang berhasil ditempuh ialah melakukan perubahan dalam rangkaian upacara adat Mappogau Hanuadari pelaksanaan ritual yang biasanya menggunakan dua waktu shalat yakni dhuhur dan ashar kemudian akhirnya dilakukan setelah usai shalat duhur sehingga hanya satu waktu shalat yang terlewatkan mengingat pelaksanaanya biasa dilakukan saat memasuki waktu dhuhur hingga sore hari bahkan menjelang magrib. Begitu pula pemotongan hewan ternak yang biasanya di bawah pohon tertentu atau di atas batu megalitik sebagai simbol ritual menjadi hanya di halaman rumah adat.

Langkah yang ditempuh Muhannis tidak serta merta diterima oleh pemangku adat mengingat Muhannis sejak awal hanya dianggap sebagai pendatang dan tidak memiliki hubungan kekerabatan di antara warga adat. Dengan intensitas keterlibatan Muhannis dalam berbagai kegiatan adat berhasil membangun hubungan emosional kekeluargaan maka belakangan usulan-usulan Muhannis tentang efektifitas kegiatan adat dapat diterima secara rasional. Strategi dakwah ini dilakukan tanpa mereduksi esensi dan nilai budaya khas ritual Mappogau Hanua sehingga pelaksanaannya diterima secara terbuka. Sedangkan di luar kegiatan ritual, dakwah pada umunya dilakukan oleh dai baik dari kalangan masyarakat sekitar maupun pendatang sebagaimana kegiatan Majlis Taklim yang rutin dan aktif dibina oleh Penyuluh Agama KUA Bulupoddo tiap hari Sabtu bulan berjalan.

Strategi ini telah menfokuskan pada tradisi membangun budaya kekeluargaan baik dari latar budaya bahasa, kesukuan, agama dan pandangan hidup antar masyarakat di mana pelaku dakwah menyesuaikan diri ke dalam masyarakat dakwah sehingga tujuan yang akan dicapai dalam kegiatan adat adalah tujuan bersama. Skema dan manajemen suatu agenda adat dilakukan dengan memfokuskan peran kerja antar elemen sehingga terbangun kepercayaan diri menuju kesuksesan kegiatan.

Upaya partisipatif dan kekeluargaan yang dibangun Muhannis secara 
Tabel 1: Unsur Persamaan

\begin{tabular}{|c|c|c|c|}
\hline \multicolumn{4}{|c|}{ UPACARA MAPPOGAU HANUA ADAT MASYARAKAT KARAMPUANG } \\
\hline \multirow[t]{2}{*}{$\begin{array}{c}\text { Rangkaian } \\
\text { Pelaksanaan } \\
\text { Upacara Adat }\end{array}$} & \multirow[t]{2}{*}{ Karakteristik } & $\begin{array}{c}\text { Sistem } \\
\text { Kepercayaan, } \\
\text { Sosial dan Budaya } \\
\text { Adat Karampuang }\end{array}$ & $\begin{array}{c}\text { Ajaran Islam } \\
\text { (aqidah dan ibadah) } \\
\text { (Ideal Oriented) }\end{array}$ \\
\hline & & \multicolumn{2}{|c|}{ Analisah Motif Persamaan } \\
\hline 1. Mabbahang & $\begin{array}{l}\text { Musyawarah internal, } \\
\text { penentuan waktu dan } \\
\text { pembagian tugas }\end{array}$ & $\begin{array}{l}\text { Dilandasi niat bersan } \\
\text { solidaritas (Pemangk } \\
\text { setempat dan warga } \\
\text { manifestasi syukur. }\end{array}$ & $\begin{array}{l}\text { lan mewujudkan } \\
\text { dat, pemerintah } \\
\text { ampuang) untuk }\end{array}$ \\
\hline 2. Mappaota & $\begin{array}{l}\text { Ritual sesajian memohon } \\
\text { restu Ieluhur pada objek } \\
\text { suci/keramat }\end{array}$ & Tidak ada motif persa & \\
\hline $\begin{array}{l}\text { 3. Mabbaja- } \\
\text { baja }\end{array}$ & $\begin{array}{l}\text { Membersihkan kawasan adat, } \\
\text { lingkungan sekitar tempat } \\
\text { upacara adat. }\end{array}$ & $\begin{array}{l}\text { Dilandasi niat bahwa } \\
\text { merupakan suatu ken } \\
\text { masyarakat sebagai r }\end{array}$ & $\begin{array}{l}\text { ersihan dan kesucian } \\
\text { ban individu dan } \\
\text { ifestasi keimanan. }\end{array}$ \\
\hline $\begin{array}{l}\text { 4. Menre ri } \\
\text { bulu }\end{array}$ & $\begin{array}{l}\text { 1. Ritual sesajian pada } \\
\text { leluhur suci/keramat. } \\
\text { 2. Ritual puncak } \\
\text { keikutsertaan dan melepas } \\
\text { nazar (hajat) } \\
\text { 3. Memperingati prosesi } \\
\text { kematian dan penguburan } \\
\text { para leluhur. }\end{array}$ & $\begin{array}{l}\text { 1. Tidak ada motif } p \\
\text { 2. Dilandasi niat un } \\
\text { tadabbur alam } \\
\text { 3. Dilandasi kesada } \\
\text { muhasabah diri } \\
\text { kematian, serta j } \\
\text { satu orang satu I } \\
\text { seddi). }\end{array}$ & $\begin{array}{l}\text { amaan } \\
\text { meramaikan dan ber- } \\
\text { bersama untuk } \\
\text { mperingati ikhwal } \\
\text { s penguburan manusia } \\
\text { g lahat (masseddi- }\end{array}$ \\
\hline $\begin{array}{l}\text { 5. Mabbali } \\
\text { Sumange' }\end{array}$ & $\begin{array}{l}\text { 1. Penyediaan kue dibuat } \\
\text { khusus oleh warga dan } \\
\text { pendukung sebagai } \\
\text { bentuk penyempurnaan } \\
\text { ritual Mappogau Hanua. } \\
\text { 2. Penyediaan ramuan } \\
\text { (bahan obat) dan } \\
\text { pemberkatan oleh Sanro } \\
\text { sebagai bentuk } \\
\text { penyempurnaan ritual } \\
\text { Mappogau Hanua.. } \\
\text { 3. Ritual pertanda warga } \\
\text { telah siap menanami } \\
\text { sawah dan kebun. }\end{array}$ & $\begin{array}{l}\text { 1. Dilandasi niat ba } \\
\text { pelengkap bahar } \\
\text { bersama. } \\
\text { 2. Dilandasi niat ba } \\
\text { ramuan/obat dar } \\
\text { keluarga. } \\
\text { 3. Dilandasi niat ke } \\
\text { melaksanakan tu } \\
\text { kesiapan warga } \\
\text { setelah dilakukar }\end{array}$ & $\begin{array}{l}\text { kue merupakan } \\
\text { kanan untuk konsumsi } \\
\text { ketersediaan } \\
\text { nenunjang kesehatan } \\
\text { ongroyongan dalam } \\
\text { kepetanian dan bentuk } \\
\text { gisi lahan pertanian } \\
\text { nen bersama. }\end{array}$ \\
\hline 6. Malling & $\begin{array}{l}\text { Berpantang selama } 3 \text { hari } \\
\text { setelah mabbali sumange' } \\
\text { atau larangan-larangan } \\
\text { memotong ternak, membuat } \\
\text { sayur dari dedaunan, } \\
\text { melakukan ritual sendiri- } \\
\text { sendiri. }\end{array}$ & $\begin{array}{l}\text { Dilandasi niat untuk t } \\
\text { sumber bahan pokok } \\
\text { (boros). }\end{array}$ & $\begin{array}{l}\text { < menggunakan } \\
\text { ara berlebih-lebihan }\end{array}$ \\
\hline
\end{tabular}


Tabel 2: Unsur Perbedaan

\begin{tabular}{|c|c|c|c|}
\hline \multicolumn{4}{|c|}{ UPACARA MAPPOGAU HANUA ADAT MASYARAKAT KARAMPUANG } \\
\hline \multirow{2}{*}{$\begin{array}{l}\text { Rangkaian } \\
\text { Pelaksanaan } \\
\text { Upacara Adat }\end{array}$} & \multirow[b]{2}{*}{ Karakteristik } & \multicolumn{2}{|c|}{ Analisah Motif Perbedaan } \\
\hline & & $\begin{array}{l}\text { Sistem Kepercayaan, } \\
\text { Sosial dan Budaya Adat } \\
\text { Karampuang }\end{array}$ & $\begin{array}{c}\text { Ajaran Islam } \\
\text { (Aqidah dan Ibadah) } \\
\text { (Ideal Oriented) }\end{array}$ \\
\hline 1. Mabbahang, & $\begin{array}{l}\text { Musyawarah, } \\
\text { penentuan waktu } \\
\text { dan pembagian } \\
\text { tugas }\end{array}$ & $\begin{array}{l}\text { Dilandasi niat sebagai } \\
\text { manifestasi syukur dan } \\
\text { mengenang leluhur }\end{array}$ & $\begin{array}{l}\text { Dilandasi niat hanya untuk } \\
\text { ibadah kepada Allah SWT }\end{array}$ \\
\hline 2. Mappaota & $\begin{array}{l}\text { Ritual sesajian } \\
\text { memohon restu } \\
\text { leluhur pada objek } \\
\text { suci/keramat }\end{array}$ & $\begin{array}{l}\text { Pemujaan pada dimensi } \\
\text { gaib/leluhur atau } \\
\text { kepercayaan transendental } \\
\text { bermotif animisme. }\end{array}$ & $\begin{array}{l}\text { Tidak ada motif aqidah dan } \\
\text { ibadah sesuai ajaran } \\
\text { Islam(orientasi syirik). }\end{array}$ \\
\hline 3. Mabbaja-baja & $\begin{array}{l}\text { Membersihkan } \\
\text { kawasan adat, } \\
\text { lingkungan sekitar } \\
\text { tempat upacara } \\
\text { adat. }\end{array}$ & $\begin{array}{l}\text { Dilakukan hanya untuk } \\
\text { menyambut tradisi adat } \\
\text { Karampuang menjelang } \\
\text { pesta adat Mappogau } \\
\text { Hanua }\end{array}$ & $\begin{array}{l}\text { Kebersihan merupakan } \\
\text { anjuran dan ibadah dalam } \\
\text { ajaran Islam. }\end{array}$ \\
\hline 4. Menre ri bulu & $\begin{array}{l}\text { 1. Ritual sesajian } \\
\text { pada leluhur } \\
\text { suci/keramat } \\
\text { 2. Ritual puncak } \\
\text { keikutsertaan } \\
\text { dan melepas } \\
\text { nazar (hajat) } \\
\text { 3. Memperingati } \\
\text { prosesi } \\
\text { kematian dan } \\
\text { penguburan para } \\
\text { leluhur. }\end{array}$ & $\begin{array}{l}\text { 1. Pemujaan pada } \\
\text { dimensi gaib, } \\
\text { mengenang leluhur } \\
\text { atau kepercayaan } \\
\text { transendental bermotif } \\
\text { animisme } \\
\text { 2. Memenuhi hajat (niat) } \\
\text { yang telah } \\
\text { direncanakan. } \\
\text { 3. Mengenang prosesi } \\
\text { kematian leluhur }\end{array}$ & $\begin{array}{l}\text { 1. Tidak ada dalam ajaran } \\
\text { Islam (orientasi syirik). } \\
\text { 2. Meramaikan dan ber- } \\
\text { tadabbur alam, } \\
\text { 3. Muhasabah dapat } \\
\text { menumbuhkan } \\
\text { kesadaran tentang } \\
\text { kematian. }\end{array}$ \\
\hline $\begin{array}{l}\text { 5. Mabbali } \\
\text { Sumange' }\end{array}$ & $\begin{array}{l}\text { 1. Penyediaan kue } \\
\text { dibuat khusus } \\
\text { oleh warga dan } \\
\text { pendukung } \\
\text { 2. Penyediaan } \\
\text { ramuan (bahan } \\
\text { obat) dan } \\
\text { pemberkatan } \\
\text { oleh Sanro. } \\
\text { 3. Ritual pertanda } \\
\text { warga telah siap } \\
\text { menanami } \\
\text { sawah dan } \\
\text { kebun. }\end{array}$ & 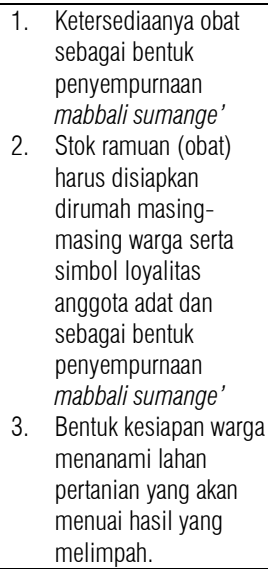 & $\begin{array}{ll}\text { 1. } & \text { Pelengkap bahan } \\
\text { makanan pokok } \\
\text { 2. } \\
\text { Ketersediaan } \\
\text { obat/ramuan dapat } \\
\text { menunjang kese- } \\
\text { hatan keluarga. } \\
\text { 3. Dilakukan untuk } \\
\text { memicu semangat } \\
\text { kerja dalam mengisi } \\
\text { lahan pertanian warga. }\end{array}$ \\
\hline
\end{tabular}




\begin{tabular}{|c|c|c|c|}
\hline 1. Malling & $\begin{array}{l}\text { Berpantang selama } \\
9 \text { hari setelah } \\
\text { mabbali sumange' } \\
\text { atau larangan- } \\
\text { larangan } \\
\text { memotong ternak, } \\
\text { membuat sayur dari } \\
\text { dedaunan, } \\
\text { melakukan ritual } \\
\text { sendiri-sendiri. }\end{array}$ & $\begin{array}{ll}\text { 1. } & \text { Menuai musibah } \\
\text { apabila memotong } \\
\text { hewan tenak } \\
\text { 2. Menggugurkan } \\
\text { tanaman pertanian } \\
\text { (menuai gagal panen). } \\
\text { 3. Menyebarnya penyakit. }\end{array}$ & $\begin{array}{l}\text { 1. Dilakukan untuk tidak } \\
\text { berlebih-lebihan } \\
\text { memotong hewan ternak } \\
\text { (stok hewan ternak tetap } \\
\text { tersedia). } \\
\text { 2. Dilakukan untuk tidak } \\
\text { berlebih-lebihan agar } \\
\text { stok tanaman pangan } \\
\text { (sayuran) tetap tersedia. } \\
\text { 3. Dilakukan agar ritual } \\
\text { besar Mappogau Hanua } \\
\text { cukup mengakomodasi } \\
\text { ritual sendiri-sendiri. }\end{array}$ \\
\hline
\end{tabular}

intens baik di dalam maupun di luar kegiatan adat telah menunjukkan adanya perubahan dinamis masyarakat Karampuang dalam menerima pandangan-pandangan luar seperti efektivitas waktu ritual, pengurangan resiko serta kemampuan masyarakat pendukung. Secara tidak lansung strategi yang dilakukan ini telah mendorong upaya dakwah bil-hal di mana peran dakwah memberikan pandangan dan pola sikap keteladanan yang dapat diterima oleh masyarakat Karampuang. Pada cakupan lebih luas kehadiran dan keberadaan masyakat pendukung telah membangun budaya partisipatif antar kelompok sehingga kepeloporan menjadi sangat penting menunjukkan peran perwakilan masing-masing masyarakat pendukung.

Berdasarkan hal tersebut maka strategi partisipatif dan kekeluargaan dalam konteks ini menunjukkan adanya beberapa fase yaitu fase adaptasi, fase asimilasi-akulturasi hingga terbentuk fase kekeluargaan. Fase adaptasi di mana seseorang dai/mubaliqh Muhammadiyah penting mengadaptasikan diri pada lingkungan adat dengan norma-norma tertentu, kebiasaan, pola hidup serta pandangan masyarakat. Pada fase asimilasiakulturasi seseorang dai/mubaliqh Muhammadiyah menyesuaikan dengan nilai-nilai lokal, Peleburan watak bersama lingkungan dan masyarakat. Sedangkan pada fase kekeluargaan adalah tahap di mana seorang dai/ mubaligh memelihara hubungan kekeluargaan baik dalam bentuk komunikasi maupun silaturahim. Pada proses ini akan terbangun pula pembinaan secara kontinyu.

\section{b. Strategi Perubahan Pola Pikir}

Mengemukakan strategi dakwah kultural jika merujuk pada struktur 
rangkaian ritual Mappogau Hanua dikemukakan beberapa konsepsi persamaan maupun perbedaan motif antara sistem kepercayaan, sosial dan budaya adat Karampuang dengan aqidah dan ibadah ajaran Islam sebagaimana terlihat pada Tabel 1 dan Tabel 2 .

Merujuk pendapat Amin bahwa fungsi dakwah kultural yang bersifat kebawah berarti menyelenggarakan dakwah dalam bentuk penerjemahan dakwah, penerjemahan ide-ide intelektual tingkat atas bagi ummat Islam serta rakyat pada umumnya untuk membawakan transformasi sosial, dengan mentransfromasikan ide-ide tersebut ke dalam konsep operasional yang dapat dikerjakan oleh ummat. ${ }^{48}$

Transformasi ide intelektual menuju purifikasi kedalam rangkaian upacara Mappogau Hanua sebagaimana pada tabel di atas dengan merujuk motif persamaan dan perbedaan antara sistem kepercayaan, sosial dan budaya adat Karampuang dengan aqidah dan ibadah ajaran Islam dikemukakan orientasi ideal (ideal oriented) sebagai peluang (opportunity) dakwah kultural Muhammadiyah. Peluang strategi ini dapat dilakukan pada rangkaian Mappgoua Hanua dari perencanaan, pelaksanaan hingga pada akhir kegiatan yaitu;

1) Mabbahang, sebagai inti kegiatan ini adalah musyarawah internal untuk mencapai mufakat. Musyawarah guna pengambilan keputusan yang tepat merupakan ajaran penting dalam agama Islam. Kata musyawarah berasal dari kata "syura" bermakna mengambil dan mengeluarkan pendapat terbaik. Dalam konteks sederhana merupakan sesuatu yang dilakukan atau konsolidasi antar pendapat umat terhadap suatu urusan penting dalam hal ini pengambilan keputusan tentang ritual dengan mengkaji waktu dan pembagian-pembagian tugas. Selain esensi musyarawah dalam Mabbabang, mengelompokkan kaum laki-laki dan perempuan secara berbeda dan kedua keputusan kelompok tersebut dipadukan sebagai keputusan final.

Pada tahapan pertama ini dapat dilakukan di antaranya adalah prosesi tilawah, tazkiyah dan ta'lim. Dengan strategi tilawah, tahap Mabbahang dimulai pelaksanaannya dengan membaca ayat suci AlQur'an sehingga dapat meransang pemikiran dan hati yang konsepsi indrawi pendengaran (al-sam') dan penglihatan (al-absar) sehingga tumbuh akal yang sehat (al-af-idah) hati yang jernih dalam mengambil keputusan. Setiap pelaksanaan suatu kegiatan anjuran tentang mengucapkan asma Allah di mana akan memberikan efek peningkatan 
iman serta mendapatkan ridho Allah SWT. Hal ini pula mengarahkan individu pada tazkiyah (penyucian jiwa) sebab mabbahang merupakan manifestasi awal dari suatu rencana kegiatan adat. Sebaliknya apabila terdapat jiwa yang kotor, niat yang tidak istiqomah maka pelaksaaannya dapat dikategorikan tidak mendapatkan keberkahan. Sedangkan ta'lim sebagai proses pengajaran, dimana pihak-pihak yang terlibat dalam Mabbahang dapat mengarahkan, mendorong dan membimbing masyarakat merenungkan serta mengambil keputusan secara bijak. Peranan Guru, da'i dan pihak terkait dalam Mabbahang dapat melakukan perubahan pola pikir atau secara rasional (al-manhaj al'aqli)yang menfokuskan pada aspek akal pikiran, mengorientasikan tujuan pada nilai-nilai solidaritas, filosofis dan religi, pelestarian alam maupun nilai-nilai seni serta manifestasi rasa syukur atas keberhasilan pertanian sesuai ajaran Islam, hal ini pula dapat mendorong praktek dari rangkaian upacara adat pada tahapan selanjutnya yang bernuansa ibadah termasuk Mappaota.

2) Mappaota. Mengingat motif ritual ini berupa ritual sesajian meletakkan benda pappaota guna pemujaan dan pada dimensi ghaib (leluhur) yang tidak memiliki kesesuaian dalam ajaran agama Islam. Maka pelaksanaan Mappaota yang menggunakan banyak waktu dan tempat berbeda maka peluang dalam rangkaian ini dapat dilakukan dengan mengganti praktek sesajian bermotif pemujaan ini menjadi praktek yang bersifat simbolis menjadi satu waktu dan tempat.

3) Mabbaja-baja (mappasyakka), membersihkan selama tiga hari dari masing-masing rumah, perkantoran, lingkungan serta sekitar kawasan adat. Sebagaimana motif utama dalam rangkaian ini dilakukan hanya dalam rangka menyambut ritual akbar Mappogau Hanua maka aktivis dakwah dapat menyikapi dengan menumbuhkan pola pikir dan membentuk kebiasaan (mindset and habit formation) masyarakat dari kegiatan yang sifatnya sekedar menyambut ritual semata menjadi aktivitas rutin yang bernilai ibadah. Dengan mendasarkan ajaran secara normatif kebersihan dan kesucian merupakan suatu anjuran dan kewajiban individu, keluarga dan masyarakat sebagai manifestasi iman dalam kehidupan sehari-hari termasuk dalam berbagai event kemasyarakatan di Karampuang.

4) Menre ri bulu, motif utama menre ribulu ialah mengenang leluhur melalui serangkaian prosesi ritual kuno (ritual sesajian, melepas nazar 
dan memperingati proses kematian leluhur). Prosesi ini dinilai tidak memiliki motif ibadah sesuai ajaran Islam oleh karena itu peran aktivis dakwah dalam reorientasi kegiatan ini dapat dilakukan melalui strategi perubahan pola pikir dan peran partisipatif masyarakat pendukung menjadi kegiatan partisipatif meramaikan dalam bentuk ber-tadabbur alam tanpa berniat melepas nazar di tahun berikutnya selain itu mendorong individu untuk menumbuhkan kesadaran bermuhasabah tentang kematian manusia.

5) Mabbali Sumange, ketersediaan kue dan ramuan obat sebagai motif penyempurnaan ritual Mappogau Hanua dan Sanro memiliki peranan sangat vital membantu hajat (niat) masyarakat adat dan pendukung. Strategi perubahan dapat dilakukan dengan membangun pemahaman rasional bahwa ketersediaan jenis kue hanya sebagai pelengkap makanan pokok guna konsumsi bersama serta ketersediaan ramuan obat dapat menunjang kesehatan keluarga. Selain itu prosesi ini diarahkan untuk memicu semangat kerja petani (warga), dilandasi semangat kegotong royongan melaksanakan tugas kepetanian sebagai manifestasi rasa syukur.

6) Malling, inti kegiatan Malling dalam keyakinan masyarakat yang berupa larangan memotong ternak, memasak sayur mayur dan melakukan ritual tersendiri dapat mendorong aktivis dakwah dalam melakukan reorientasi dan strategi secara rasional seperti larangan memotong hewan ternak dan memasak sayur dedaunan dimaksudkan agar stok hewan ternak dan sayur mayur tetap tersedia setelah dilakukannya upacara besar Menre Ribulu yang telah memanfaatkan hewan ternak dalam jumlah banyak. Larangan melakukan ritual secara sendiri-sendiri dapat dimaksudkan bahwa ritual Mappogau Hanua telah dapat mengokomodasi ritual-ritual kecil. Oleh karena itu inti dari strategi ini dapat lebih mengarah pada bentuk larangan berlebih-lebihan dalam menggunakan bahan makanan pokok.

\section{Strategi Pembinaan}

Di antara peranan pemerintah daerah dalam upacara adat Mappogau Hanua adalah pembinaan melalui pelestarian budaya, keterlibatan ini menunjukkan adanya indikasi pembinaan melalui skema budaya. Sebagai suatu pendekatan struktural maka strategi pembinaan adalah alternatif tepat dakwah kultural ini akan tetap berlansung. Peran pemerintah yang 
berperan penting mengakomodasi pelaksanaan upacara adat Mappogau Hanua mendapatkan porsi lebih besar dalam mendekati sasaran dakwah sebagai strategi dakwah. Pembinaan dalam konteks ini di mana dalam struktur pemerintahan adat keberadaan To Matoa dan Gella' sebagai pengendali adat menjadi upaya pendekatan pemerintah membangun relasi dan kerja sama yang sifatnya pembinaan. Upacara adat Mappogau Hanua sebagai wadah pokok yang menyatukan unsur adat, pemerintah dan masyarakat pendukung merupakan entitas yang saling membutuhkan sehingga strategi pembinaan terbangun sebagai suatu pola kerjasama. Secara praktis strategi ini dapat dilakukan dengan meningkatkan porsi perhatian dalam menumbuhkembangkan kegiatan-kegiatan masyarakat desa berbasis budaya yang terbingkai nilai-nilai ajaran Islam.

Setiap rangkaian kegiatan pada upacara adat Mappogau Hanuadari prosesi awal hingga akhir serta bentuk ritual adat lainnya memiliki peluang (opportunity) bagi aktivis dakwah melakukan upaya persuasif dan kolektif baik masyarakat adat dan pengendali kebijakan adat seperti Gella', Sanro dan Guru secara lansung melalui pembinaan dan pembentukan kebiasaan (habit formation) secara berkelanjutan. Guru sebagai pemangku dan sebagai pilar adat sangat berperan dalam membangun pondasi keagamaan dan pendidikan, kepadanya terpusat kebijakan SDM generasi masyarakat adat dimasa yang akan datang. Maka penguatan pondasi kebijakan peranan Guru penting mendapat dorongan dan pembinaan dari segenap pihak terutama para dai Muhammadiyah Kabupaten Sinjai secara intens termasuk guru-guru maupun penyuluh agama. Secara aplikatif upaya ini dapat dilakukan dengan membantu pilar Guru dalam merumuskan dan mengimplementasikan program-program kegiatan pendidikan dan keagamaan secara nyata dan berkala yang memberikan efek positif secara lansung bagi masyarakat dan generasi adat termasuk intensitas pada momentum kegiatan keagamaan dibulan ramadhan.

Peranan Sanro sebagai pelaksana bidang kesehatan masyarakat dapat dijadikan fokus dalam pembinaan kalangan tenaga kesehatan dimana prinsip, nilai-nilai dan tujuan pelayanan kesehatan dapat diintegrasikan dalam budaya masyarakat sehingga nuansanya dakwah bil al-lisan dan dakwah bil al-hal senantiasa terbangun. Adanya kemungkinan tenaga kesehatan menjangkau masyarakat Karampuang telah menujukkan sebagai suatu strategi dakwah dengan pola kerja sama Sanro' sesuai dengan bidang dan kemampuan masing-masing hal ini berwujud pada praktek pembinaan 
sebagai suatu strategi dakwah kultural.

Di sisi lain generasi muda masyarakat Karampuang sebagai pelanjut otoritas adat dimasa mendatang dapat menjadi fokus pembinaan melalui aspek kebudayan, pendidikan dan keagamaan. Pembinaan pada aspek ini dapat dilakukan dengan upaya pendampingan pada kegiatan-kegiatan berbasis masyarakat dan kepemudaan serta dorongan pembentukan kualitas pengetahuan, keterampilan dan spiritualitas keagamaan baik melalui jalur formal, non formal maupun informal sehingga yang dihasilkan pada masa-masa mendatang adalah generasi yang mampu berpikir dan bertindak secara rasional dan produktif.

\section{Efektifitas Dakwah Kultural dalam Upacara Adat Mappogau Hanua}

Dakwah kultural di masyarakat Karampuang senantiasa beriringan dengan tantangan dalam berbagai prakteknya. Mappogau Hanuasebagai suatu tradisi multidimensi yang sangat langka di tengah masyarakat modern sehingga masyarakatnya cenderung memiliki loyalitas tinggi pada tradisi warisan leluhur. Praktek dakwah kultural di Karampuang dihadapkan pada tantangan disebabkan yaitu; Pertama, masyarakat adat Karampuang memiliki budaya material yakni benda megalitik sebagai pusat kepercayaan, sosial budaya maupun keagamaan yang menjadi simbol keberlansungan tradisi adat sehingga menjadi tantangan tersendiri bagi mubaligh (dai) dalam melakukan dakwah. Kedua, masyarakat adat Karampuang memiliki kerangka konsep adat yang terhimpun dalam Lontara Karampuang (kitab lontara) serta tradisi lisan Pappaseng dan simbol ideal yang harus termanifestasi dalam pola pikir dan pola sikap dalam kehidupan bermasyarakat termasuk kewajiban adat dalam melaksanakan ritual adat Mappogau Hanua.

Interpretasi terhadap ritual adat initidak dapat sekedar dimaknai sebagai aktivitas yang banyak menyimpang dari ajaran Islam. Pelaksanaan ritual tersebut sebagai aktivitas komunal dan masif dilaksanakan secara sukarela dan ikhlas oleh pendukungnya untuk tidak sekedar menjalankan ritual. Mengamati rangkaian upacara adat Mappogau Hanua dimana prinsip, fungsi dan tujuan, nilai-nilai dan konsepnya yang masih memiliki kerelevansian nilai-nilai ajaran Islam maka integrasi dakwah Islam dapat lebih mengokohkan kegiatan adat ini yang akan menekankan tradisi nilai dan bertumpu pada tiga prinsip yaitu Tabsyir, Islah dan Tajdid (TIT). Hal ini 
pula dapat menjadikan upacara adat Mappogau Hanua sebagai wadah dan media dakwah bagi masyarakat.

Kegiatan dakwah kultural tidak serta merta dilakukan secara kebetulan namun aktifitas dakwah memerlukan pendekatan-pendekatan konkrit dan ikhtiar secara terus-menerus, sistematis, komprehensif serta mempertimbangkan masyarakat dan konsep adat. Sehingga untuk mengembalikan ajaran Islam secara murni yang terkait Mappogau Hanua dalam eksistensi masyarakat Karampuang maka memerlukan waktu yang relatif lama. Hal ini didasarkan pada efektivitas dakwah yang diharapkan berhasil dan tepat. Oleh karena itu dibutuhkan SDM yang cukup dan mumpuni dalam pelaksanaan teknis dakwah kultural khususnya dalam rangkaian ritual, disamping pula penting adanya kerja sama pihak termasuk perguruan tinggi yang dapat dimanfaatkan. Dalam konteks ini maka mubaligh (dai) Muhammadiyah sangat penting mengaktualisasikan diri sebab merupakan potensi dan lahan dakwah sekaligus sebagai tantangan dalam dakwah kultural lokal yang diharapkan bermuara pada suatu inovasi dakwah yang dapat lebih merekonstruksi kegiatan bermotif ritual adat dari perspektif yang berbeda yang lebih sesuai dengan ajaran Islam.

Di samping dakwah kultural di masyarakat adat Karampuang juga diperlukan adanya implementasi kongkrit Gerakan Jamaah dan Dakwah Jamaah (GJDJ) secara lansung. Tentu dapat terbangun melalui pendekatan kekeluargaan yang dapat dimulai dari unsur pilar adat, pemerintahan desa serta masyarakat adat secara keseluruhan melalui pembudayaan nilai-nilai kehidupan yang lebih Islami. Dengan konsep GJDJ yang terimplementasi akan sangat berperan penting sebagai strategi penguatan dakwah kultural dalam lingkup terkecil (keluarga) hingga lingkup luas masyarakat Karampuang termasuk pada ritual adat Mappogau Hanua. GJDJ melalui gerakan aktivisnya akan turut menumbuhkembangkan nilai-nilai spiritual dan budaya baru yang memiliki keterkaitan dengan sikap mental, pandangan hidup dan tujuan individu masyarakat adat yang berdampingan dengan sistem ritual Mappogau Hanua. Oleh karena itu untuk dapat mewujudkan pergeseran dan perubahan pandangan hidup serta sistem ritual adat ini maka diperlukan adanya kemauan, kemampuan dan komitmen inisiatif penggerak dakwah untuk menjadi bagian dari warga masyarakat adat dalam jangka waktu yang lama dengan tetap bertumpu pada dimensi kerisalahan, kerahmatan dan kesejarahan dalam kehidupan masyarakat adat Karampuang. 
Karampuang sebagai aset dalam dimensi pariwisata dengan ritual adatnya yang menarik minat wisatawan maka mempertahankan ritual adat merupakan sifat dasar manusia (human nature) yang selalu ingin berhubungan dengan alam sekitarnya hal ini dapat pula berarti sebagai suatu skenario rasional yang harus dieksistensikan oleh masyarakat adat dan pendukungnya guna teguhnya konsep adat dan sistem pemerintahan tradisional. Sebagai masyarakat local (adat) yang menonjol dari segi budaya serta pengaruh kepentingan dan budaya luar dapat menjadi tantangan dai dalam melakukan dakwah.

\section{KESIMPULAN}

Paparan keberadaan dan eksistensi komunitas adat Karampuang dalam kebudayaan masyarakat Bugis dengan pengendalian pemerintahan adat oleh Ade' Eppa'e (empat unsur adat) maupun tradisi ritual adatnya seperti Mappogau Hanua yang bermotif aqidah telah terkonsep dalam Pappaseng dan Lontara yang merupakan local wisdom. Mappogau Hanua sebagai simbol pengakuan dan pengukuhan diri pada dimensi leluhur yang merupakan aktivitas budaya yang lahir sejak pra Islam dan bertahan hingga sekarang sehingga masyarakat adat disamping menjalankan ajaran agama Islam juga menjalankan tradisi leluhur yang bermotif animisme. Mappogau Hanua yang menekankan rangkaian aktivitas ritul adat telah menciptakan relasi sosial yang kuat dan wadah silaturahmi antar keluarga dan masyarakat. Secara normatif merupakan bentuk kesyukuran kepada Sang Khalik (Allah SWT) sehingga nilai-nilai yang terkandung dalam aktivitas ini yakni nilai solidaritas (persatuan), nilai filosofi dan religi, nilai pelestarian alam maupun nilai seni. Rangkaian, nilai-nilai yang relevan dalam ajaran Islam berhasil membuka cakrawala pemikiran dan strategi dakwah kultural sebagai suatu transformasi intelektual.

Sajian artikel ini memiliki kontribusi dalam dakwah kultural Muhammadiyah terutama strategi dakwah dalam budaya lokal (adat) masyarakat dengan tradisi-tradisi ritual adatnya. Transformasi strategi dakwah menuju purifikasi ini dapat dimulai (1) strategi partisipatif dan kekeluargaan yakni memahami motif masyarakat adat dan pendukungnya sebagai komunitas budaya melalui keterlibatan diri pada berbagai selukbeluk kehidupan adat secara kekeluargaan. (2) Strategi perubahan pola pikir yaknimenawarkan ide-ide rasional dalam setiap rangkaian ritual adat, (3) strategi pembinaan yakni pendampingan, pembinaan dan penguatan 
pondasi kebijakan pilar adat (Guru) dan (Sanro) sebagai penanggung jawab pendidikan dan keagamaan dan kesehatan. Dengan berangkat pada langkah strategiyang tepat dan terbingkai ajaran agama Islam dalam kegiatan dakwah maka akan terbangun pola dakwah kultural yang efektif menuju Islam yang rahmatan lil alamin.

Kegiatan dakwah kultural Muhammadiyah dengan strategi-strategi pendekatannya penting untuk selalu dipertahankan, dikembangkan sehingga dapat menjadi pioner pengembangan dakwah pada masyarakat adat dengan tingkat kompleksitas yang tinggi dalam mengatasi bentukbentuk penyimpangan aqidah. Kegiatan dakwah kultural di Karampuang Kab. Sinjai perlu ditopang oleh manajemen dakwah yang solid dan konsisten serta pelaksanaannya yang benar-benar menyentuh dimensi kehidupan tradisi adat masyarakat tanpa menghilangkan identitas khas suatu tradisi. Sehingga penting adanya penyusunan konsep baku strategi dakwah secara khusus serta muatan pembinaanya yang terintegrasi dalam konsep adat rangkaian upacara Mappogau Hanua. Bagi segenap pihak (stakeholder) pentingnya dukungan secara menyeluruh dan terlibat aktif dalam upaya memberikan dorongan pelaksanaan dakwah sebagai suatu misi amar ma'ruf nahi mungkar di tengah dinamika masyarakat yang terus mengalami perubahan.

\section{Ucapan Terima Kasih}

Naskah ini merupakan hasil penelitian yang dibiayai oleh Skema Hibah Muhammadiyah Abad Kedua tahun 2017. Ucapan terima kasih kepada; (1) Majelis Diktilitbang Pimpinan Pusat Muhammadiyah atas hibah penelitian yang diberikan serta saran dari tim reviewer tentang naskah ini, (2) P3M IAIM Sinjai yang senantiasa mendorong penulis dalam penelitian, (3) Para tokoh, budayawan maupun pengurus daerah Muhammadiyah Sinjai dalam diskusi-diskusi. (4) Para tokoh adat dan masyarakat Karampuang yang menerima penulis dengan penuh kekeluargaan serta memberikan informasi yang sangat berharga. Semoga hasil penelitian ini senantiasa bernilai ibadah disisi Allah SWT.

\section{CATATAN AKHIR}

1 Weinata Sairin, Gerakan Pembaharuan Muhammadiyah, (Jakarta: Pustaka, Sinar Harapan, 1995), h.48-49.

2 Koenjtaraningrat, Kebudayaan: Mentalitas dan Pembangunan, (Jakarta: Gramedia 
Pustaka Utama, 1993), h. 243-246.

3 Imam Suprayogo, Metodologi Penelitian Sosial-Agama, (Bandung; Remaja Rosda Karya: Bandung, 2001), h. 41.

4 Adi Sasono dkk, Solusi Islam atas Problematikan Umat: (Ekonomi, Pendidikan dan Dakwah), (Jakarta: Gema Insani Press, 1998), h. 175.

5 PP Muhammadiyah, Dakwah Kultural Muhammadiyah, (Yogyakarta; Suara Muhammadiyah 2004).

6 Muhannis, Karampuang dan Bunga Rampai Sinjai, (Yogyakarta: Ombak, 2009), h. 4-5.

7 Sugiono, Metode Penelitian Kuantitatif, Kualitatif dan REDD, (Bandung: Alfabeta, 2009), h. 246.

8 Agus Bustanuddin, Islam dan Pembangunan (Islam dan Muslim Serial Esai Sosiologi Agama I, (Jakarta; Raja Grafindo Persada 2007), h. 194.

9 Sonny A. Keraf, Etika Lingkungan Hidup,(Jakarta: Kompas Media Nusantara, 2010), h. 326.

10 Abdullah bin Abdul Hamid Al-Atsari, dalam http://pustakaimamsyafii.com/ definisi-aqidah.html, diakses pada tanggal 17 Maret 2017.

$11 \quad$ KBBI, Ofline, Edisi 1.4

12 Rosyad Saleh, Manajemen Dakwah Muhammadiyah, (Yogyakarta: Suara Muhammadiyah, 2005), h. 37-38.

13 Wina Sanjaya, Strategi Pembelajaran Berorientasi Standar Proses Pendidikan, (Jakarta: Kencana Prenada Media Group, 2007), h. 124.

14 Rosyad, Saleh, Manajemen.,

15 Moh Ali Azis, Ilmu Dakwah, Cet. 2.(Jakarta: Kencana, 2009), h.6

16 Muhammad Sulton, Menjawab Tantangan Zaman, Desain Ilmu Dakwah, Kajian Ontologis, Epistemologis, dan Aksiologis, (Yogyakarta, Pustaka Pelajar, 2003), h. 4-13.

17 Said Abdul Aziz, Toraja: Simbolisme Unsur Visual Rumah Tradisional, (Yogyakarta: Ombak.2004), h. 19-20.

18 Said Abdul Aziz, Toraja: Simbolisme, h. 350.

19 Muhyiddin Asep \& Safei Ahmad Agus, Metode Pengembangan Dakwah, (Bandung: Pustaka Setia, 2002), h.79.

20 Samsul Munir Amin, Ilmu Dakwah, (Jakarta; Amzah, 2009), h. 99.

21 Faizah \& Lalu Muchsin Effendi, Psikologi Dakwah, (Jakarta: Kencana, 2009).

22 Samsul Munir Amin. Ilmu Dakwah, h. 11

23 Said Abdul Aziz. Toraja: Simbolisme, h. 355.

24 Samsul Munir Amin. Ilmu Dakwah, h. 108.

25 Muhammad Sulton, Menjawab Tantangan, $h .18$.

26 Suara Muhammadiyah, No.02 th 2005.

27 Samsul Munir Amin, Ilmu Dakwah, h. 163 \&107

28 Said Abdul Aziz, Toraja: Simbolisme, h. 349.

29 Muhannis, Karampuang.,

30 Muhannis. Peran Tradisi Lisan Pappaseng pada Masyarakat Adat Karampuang dalam Penyelesaian Konflik. Sinjai, Makalah Presentasi, 2014, h. 2. 
3 Muhannis. Peran Tradisi, liat juga: Basrah, Sistem Pengetahuan Lokal dalam Pengelolaan Hutan Berbasis Masyarakat di Kawasan Hutan Adat Karampuang, Tesis, (Makassar:PPs Universitas Hasanuddin, 2005)

34 Muhannis. Peran Tradisi.

35 Moh Yahya Mustafa dan Tungke Wanua A., Sinjai 10 Tahun dalam Memori, (Makassar: Pustaka Refleksi, 2002), h. 3.

36 Muhannis, Karampuang dan.

37 Mattulada, Agama Islam di Sulawesi Selatan, dalam Taufik Abdullah, (ed), Agama dan Perubahan Sosial, (Jakarta: Rajawali Press, 1982), h. 153.

38 Muh. Anis, "Kontekstualisasi Ibrah Sejarah (Penerimaan Islam di Sinjai pada Abad XVII)" dalam Jurnal Al-Qalam, Vol. 5. No. 2 (2013), h. 168.

39 Haedar Nashir, Islam Syariat: Reproduksi Salafiyah Ideologis di Indonesia, (Bandung: Mizan Pustaka, 2013), h. 301.

40 Muhannis, Karampuang dan.

41 Muhannis, Karampuang dan.

42 Wawancara Magga' 24 Maret 2017.

43 Muhannis, Karampuang dan.

44 Abdullah Renre, Patuntung di Sinjai Barat, Suatu Tinjauan Sosio-Kultural, (Makassar: Alauddin University Press, 2012), p. 131.

45 Muhannis, Karampuang dan.

46 Wawancara Anis, 5 April 2017

47 Wawancara Mangga', 27 Maret 2017.

48 Samsul Munir Amin. Ilmu Dakwah

\section{DAFTAR PUSTAKA}

Agus, Bustanuddin. 2007. Islam dan Pembangunan (Islam dan Muslim Serial Esai Sosiologi Agama I. Jakarta: Raja Grafindo Persada.

AMAN Sinjai. 2015. Pemetaan Partisipatif Wilayah Adat Kab. Sinjai.

Amin, Munir Samsul. 2009. Ilmu Dakwah. Jakarta: Amzah.

Anis, Muh. 2013. "Kontekstualisasi Ibrah Sejarah (Penerimaan Islam di Sinjai pada Abad XVII).” Jurnal Al-Qalam, Vol. 5. No. 2.

Aziz, Moh Ali. 2009. Ilmu Dakwah, Cet. 2. Jakarta: Kencana.

Aziz, Said Abdul. Toraja: Simbolisme Unsur Visual Rumah Tradisional. Yogyakarta: Ombak.2004.

Basrah, 2005. "Sistem Pengetahuan Lokal dalam Pengelolaan Hutan Berbasis Masyarakat di Kawasan Hutan Adat Karampuang.” Tesis. Makassar; Program Pascasarjana Universitas Hasanuddin.

Departemen Agama RI. 2009. Al-Qur'an Al-Karim dan Terjemah-Nya. Bandung: PT. Sygma Examedia Arkamlema.

Direktorat Perlindungan dan Kesejahteraan Masyarakat BPPN. 2013. Masyarakat Adat di Indonesia: Menuju Perlindungan Sosial yang Inklusif. Jakarta: t.p.

Faizah dan Lalu Muchsin Effendi. 2009. Psikologi Dakwah. Jakarta: Kencana. 
Hafiduddin D., Sasono Adi. 1998. Solusi Islam atas Problematika Umat: (Ekonomi, Pendidikan dan Dakwah). Jakarta: Gema Insani Press.

http://pustakaimamsyafii.com/definisi-aqidah.html, diakses pada tanggal 17 Maret 2017.

KBBI, Ofline, Edisi 1.4

Keraf, Sonny A. 2010. Etika Lingkungan Hidup. Jakarta: Kompas Media Nusantara.

Koenjtaraningrat. 1993. Kebudayaan: Mentalitas dan Pembangunan. Jakarta: Gramedia Pustaka Utama.

Mattulada. 1983. "Agama Islam di Sulawesi Selatan.” dalam Taufik Abdullah, (ed). Agama dan Perubahan Sosial. Jakarta: Rajawali Press.

Muhammadiyah, PP. 2004. Dakwah Kultural Muhammadiyah. Yogyakarta: Suara Muhammadiyah.

Muhannis. 2009. Karampuang dan Bunga Rampai Sinjai. Yogyakarta:Ombak. . 2014. Peran Tradisi Lisan Pappaseng pada Masyarakat Adat Karampuang dalam Penyelesaian Konflik. Sinjai. Makalah Presentasi.

Muhyiddin, Asep \& Safei, Ahmad A. 2002. Metode Pengembangan Dakwah. Bandung; Pustaka Setia.

Mustafa, Moh Yahya \& Tungke,Wanua A. 2002. Sinjai 10 Tahun dalam Memori. Makassar: Pustaka Refleksi.

Nashir, Haedar. 2013. Islam Syariat: Reproduksi Salafiyah Ideologis di Indonesia. Bandung: Mizan Pustaka.

Renre, Abdullah. 2012. Patuntung di Sinjai Barat, Suatu Tinjauan Sosio-Kultural. Makassar: Alauddin University Press.

Said, Abdul Aziz. 2004. Toraja: Simbolisme Unsur Visual Rumah Tradisional. Yogyakarta: Ombak.

Sairin, Weinata. 1995. Gerakan Pembaharuan Muhammadiyah. Jakarta: Pustaka Sinar Harapan.

Saleh, Rosyad. 2005. Manajemen Dakwah Muhammadiyah, Cet. II. Yogyakarta: Suara Muhammadiyah.

Sanjaya, Wina. 2006. Strategi Pembelajaran Berorientasi Standar Proses Pendidikan, Cet. 2, Jakarta: Kencana Prenada Media Group.

Sasono, Adi, Didin Hafidhuddin, A.M. Saefuddin, dkk., 1998. Solusi Islam atas Problematikan Umat: (Ekonomi, Pendidikan dan Dakwah). Jakarta: Gema Insani Press.

Sugiono. 2009. Metode Penelitian Kuantitatif, Kualitatif dan REDD. Bandung: Alfabeta.

Sulton, Muhammad. 2003. Menjawab Tantangan Zaman, Desain Ilmu Dakwah, Kajian Ontologis, Epistemologis, dan Aksiologis. Yogyakarta: Pustaka Pelajar.

Suprayogo, Imam. 2001. Metodologi Penelitian Sosial-Agama. Bandung: Remaja Rosda Karya.

\section{WAWANCARA KHUSUS:}

P. Magga'(L) "Gella Karampuang”(60 tahun)

P.Jenne' (P) "Sanro Karampuang” (60 tahun) 
P. Kasyong (L) "GuruKarampuang” (60 tahun)

Muh. Anis (L), (Peneliti, aktivis dakwah Muhammadiyah), (36 tahun)

Drs. Muhannis, (Budayawan atau Peneliti Budaya), (66 Tahun),

Rahmatullah Harum (72 tahun) (Tokoh Muhammadiyah dan tokoh pendidikan) 